\title{
WEB INDICATORS FOR RESEARCH EVALUATION. PART 1: CITATIONS AND LINKS TO ACADEMIC ARTICLES FROM THE WEB
}

\author{
Indicadores web para evaluación de la investigación. \\ Parte 1: Citas y enlaces a artículos \\ académicos desde la Web
}

\section{Mike Thelwall and Kayvan Kousha}

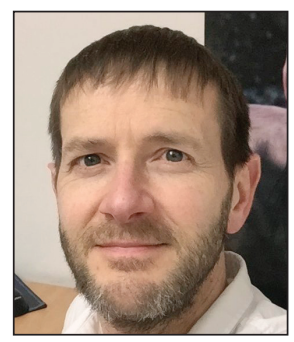

Mike Thelwall is the head of the Statistical Cybermetrics Research Group at the University of Wolverhampton, UK. He has developed a wide range of software for gathering and analysing web data, including hyperlink analysis, sentiment analysis and content analysis for Twitter, YouTube, Myspace, blogs and the web in general. http://orcid.org/0000-0001-6065-205X

m.thelwall@wlv.ac.uk

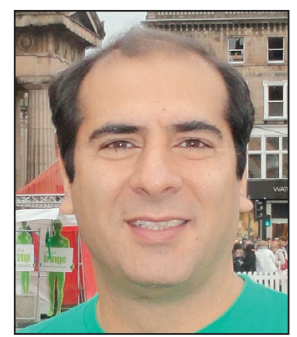

Kayvan Kousha is a researcher in the Statistical Cybermetrics Research Group at the University of Wolverhampton, UK. His research includes web citation analysis and online scholarly impact assessment using webometrics and altmetrics methods. He has tested different web citation extraction methods from various types of web documents such as Google Books, Google Patents, academic course syllabi and online book reviews for research evaluation.

http://orcid.org/0000-0003-4827-971X

k.kousha@wlv.ac.uk

Statistical Cybermetrics Research Group, School of Mathematics and Computer Science, University of Wolverhampton Wulfruna Street, Wolverhampton WV1 1LY, United Kingdom

\begin{abstract}
The extensive use of the web by many sectors of society has created the potential for new wider impact indicators. This article reviews research about Google Scholar and Google Patents, both of which can be used as sources of impact indicators for academic articles. It also briefly reviews methods to extract types of links and citations from the web as a whole, although the indicators that these generate are now probably too broad and too dominated by automatically generated websites, such as library and publisher catalogues, to be useful in practice. More valuable web-based indicators can be derived from specific types of web pages that cite academic research, such as online presentations, course syllabi, and science blogs. These provide evidence that is easier to understand and use and less likely to be affected by unwanted types of automatically generated content, although they are susceptible to gaming.
\end{abstract}

\section{Keywords}

Webometrics; Altmetrics; Alternative metrics; Alternative indicators; Citation analysis; Web indicators; Scientometrics; Google Scholar.

\section{Resumen}

El gran uso de la web por parte de muchos sectores de la sociedad ha creado el potencial para nuevos indicadores de impacto más amplios. Este artículo revisa la investigación sobre Google Scholar y Google Patents, servicios que pueden ser utilizados como fuente de indicadores de impacto de artículos académicos. También se examinan brevemente los métodos para extraer tipos de enlaces y citas de la Web en su conjunto, aunque para que sean útiles en la práctica los indicadores que éstos generan ahora son probablemente demasiado amplios y demasiado dominados por sitios web generados automáticamente, como catálogos de biblioteca y de editoriales. Indicadores basados en la web más valiosos se pueden derivar 
de determinados tipos de páginas web que citan investigaciones académicas, tales como presentaciones online, programas de cursos y blogs científicos. Éstos proporcionan evidencia más fácil de entender y de usar, y son menos propensos a ser afectados por los tipos indeseados de contenido generados de forma automática, aunque son susceptibles de ser falseados.

\section{Palabras clave}

Webmetría; Altmétricas; Indicadores alternativos; Métricas alternativas; Análisis de citas; Indicadores Web; Cienciometría; Google Académico.

Thelwall, Mike; Kousha, Kayvan (2015). "Web indicators for research evaluation. Part 1: Citations and links to academic articles from the Web". El profesional de la información, v. 24, n. 5, pp. 587-606.

http://dx.doi.org/10.3145/epi.2015.sep.08

\section{Introduction}

The need to evaluate the contributions of researchers, research groups, departments or collections of papers occurs in many situations, including job applications, promotion decisions, research assessment exercises, research funding programme assessments, and grant applications. Although peer judgements are commonly used in such cases, quantitative indicators may sometimes aid the decision making: "to inform, but not to determine, judgements of research quality" (Warner, 2000, p. 453). These quantitative indicators have mainly been based on citations in traditional citation indexes, such as the Web of Science (WoS) and Scopus. Although controversial and frequently misused, judicious

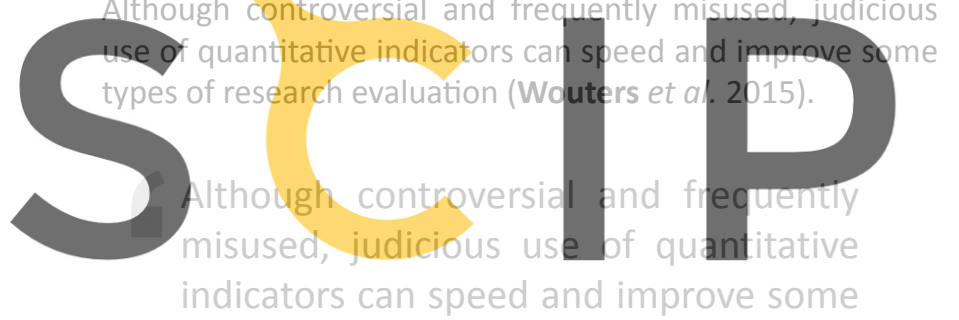

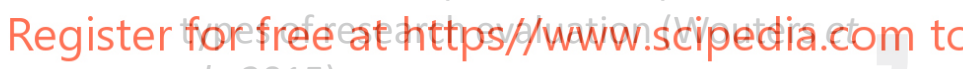
al., 2015)

Despite agreement that traditional citation databases are the best sources of data for indicators to help peer review for research evaluation, some aspects of intellectual impact are not well reflected in conventional citation indexes. For example, citation indexes are not comprehensive and are mainly restricted to English language refereed journal articles, with weaker coverage of books and conference papers. Another problem is that publications may be used during the research process or for other academic-related activities, such as teaching, without being formally cited. More generally, citation databases are unlikely to be useful to track the wider impacts of research, such as on business, government and society. Hence, research that has important societal or cultural impacts may be systematically undervalued if assessed with the aid of citation-based indicators. Thus, it is clear that other data sources are needed if quantitative indicators can be used to aid the evaluation of the wider impacts of academic research.

Peer review seems to be more reliable than citation counting for research evaluation and hence is the first choice in most cases, although subjective perceptions of research quality may cause many different types of bias (Lee; Sugimoto; Zhang; Cronin, 2013) and finding expert reviewers can also be difficult (Weller, 2001). Expert judgments can also be time-consuming and expensive, especially for large research assessment exercises. For instance, in the 2008 UK Research Assessment Exercise (RAE) for Biological Sciences each of the subject specialist evaluators (mostly senior professors) assessed about 1,000 papers "within a few months" (Eyre-Walker; Stoletzki, 2013, p. 7) and some Social Sciences and Humanities evaluators had to evaluate about 100 books within the same timeframe (Kousha; Thelwall; Rezaie, 2011). Thus, even for important evaluations that drive major funding decisions, such as this one, there may be too

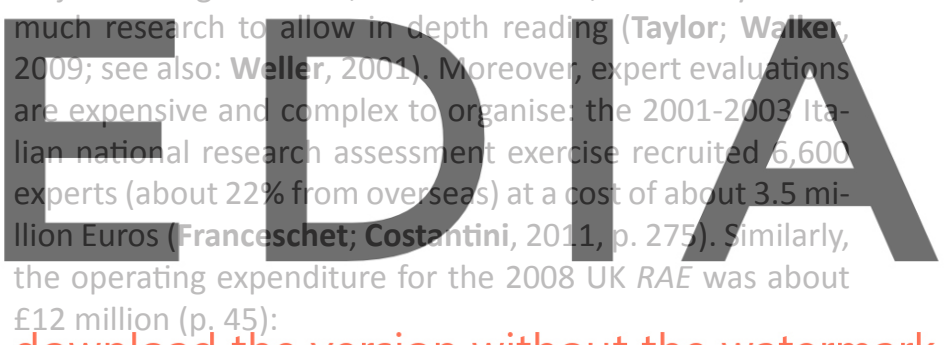
f12 million ( $p, 45)$ :

Hence, any quantitative indicators that could make research evaluations cheaper could be extremely valuabie.

More than a decade ago, the development of new ways for scholars to write, communicate and publish (e.g., Kling; McKim, 1999, 2000) led to calls for novel indicators for electronic scholarly communication (Ingwersen, 1998; Cronin, 2001; Borgman; Furner, 2002). These alternative metrics include web citations in digitised scholarly documents (e.g., eprints, books, science blogs or clinical guidelines) or, more recently, altmetrics (Priem; Taraborelli; Groth; Neylon, 2010) derived from social media (e.g., social bookmarks, comments, ratings, tweets). In theory, alternative metrics may be helpful when evaluators, funders or even national research assessment need to know about "social, economic and cultural benefits and impacts beyond academia" (REF, 2011, p. 4) as well as non-standard impacts inside academia.

This is the first of a three part literature review of web indicators helpful for research assessment of academics articles. This part starts with Google Scholar. Although primarily a free search engine for academic articles, it includes citation counts for these articles and so functions as a citation index that can be used for research impact indicators. Google Patents, in contrast, does not provide citation counts for the academic 
articles cited by the patents that it indexes but can nevertheless be used indirectly to identify citations from patents. Web links are the earliest source of web impact indicators used, and this article discuses methods to identify different types of links to academic articles and indicators of overall web impact derived from them. More specific types of impact indicators can also be derived from the web by restricting the focus to a specific type of academic-related website, or even file type, and this paper finished by reviewing the evidence that indicators from links or mentions in online syllabi, science blogs or presentations can be useful.

In most cases, the main evidence for the value of an indicator is a statistically significant and positive correlation with citation counts. Although this is a logical first step to assess any new quantitative indicator it is almost paradoxical in that a perfect correlation would indicate that two indicators were essentially identical, whereas the claim for most new indicators is that they reflect something different from that of citation counts. Nevertheless, a positive correlation between a new indicator and citation counts is empirical evidence that the new indicator reflects something related to academic communication, rather than being purely spam or random, and the strength of the correlation can suggest the extent to which the two are similar (Sud; Thelwall, 2014b). The correlation strength should be evaluated in the context of the range of ages of the articles assessed and the breadth

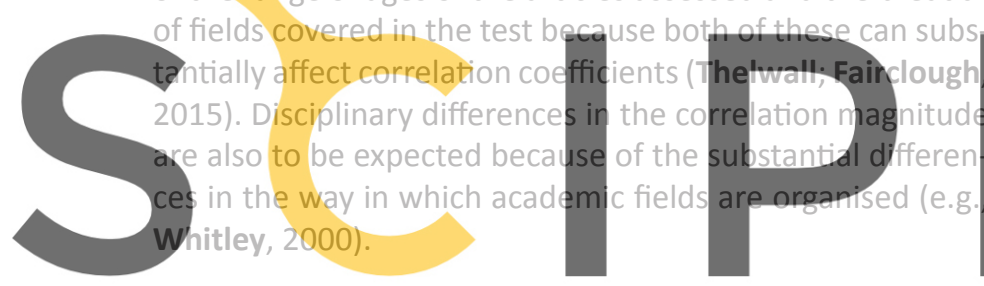

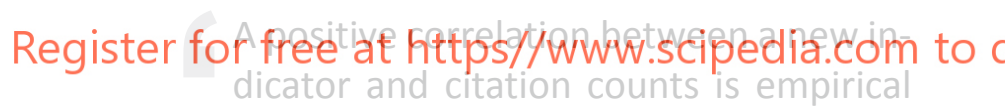
evidence that the new indicator reflects something related to academic communication, rather than being purely spam or random

\section{Limitations of traditional citation databases: A brief overview}

The citation-based indicators used for research evaluation are imperfect and have many limitations that should be considered when they are used (see MacRoberts; MacRoberts, 1989, 1996; Moed, 2005a). Currently (July, 2015), Thomson Reuters claims that its citation indexes cover about 12,000 core journals, 160,000 conference proceedings and 50,000 editorially selected books:

http://wokinfo.com/products_tools/multidisciplinary/ webofscience

The growth rate of its Science Citation Index $(S C I)$, however, seems to be smaller than that of other comparable databases, suggesting that it may be covering a decreasing proportion of the scientific literature, especially in the Social Sciences (Larsen; Von Ins, 2010).
Using traditional citation databases for research evaluation in the Social Sciences, Arts and Humanities is more problematic than in Science and Medicine. This is because scholars in these areas are more likely to author types of publications, and in languages other than English, that are underrepresented in, or absent from, traditional citation indexes (Moed, 2005a; Nederhof, 2006; Huang; Chang, 2008). For example, less than $10 \%$ of Australian universities' academic publications 1999-2001 were in Thomson Scientific's citation indexes in some areas (Butler, 2008) and under 30\% of the (selective) outputs of some Arts and Humanities fields in the 2001 UK Research Assessment Exercise (RAE) were in the Web of Science (WoS) (Mahdi; D'Este; Neely, 2008). Just under half (48\%) of 4,600 publications by researchers from three UK business schools over the period 2001-2007 in Business and Management were in WoS, whereas Google Scholar searches found $66 \%$ of these publications, including $90 \%$ of the journal articles (Mingers; Lipitakis, 2010). Furthermore, no significant correlations have been found in 9 out of 28 subject areas for the 2001 UK RAE between WoS citations and RAE peer review scores in Social Sciences and Humanities fields (e.g., Education, Sociology, History, Politics, International Studies), whereas in most science fields moderate to high correlations have been found (Mahdi; D'Este; Neely, 2008, p. 16). One of the reasons for the low WoS coverage of Humanities RAE submissions is that about $16.5 \%$ of all submissions to the 2008 UK RAE were books

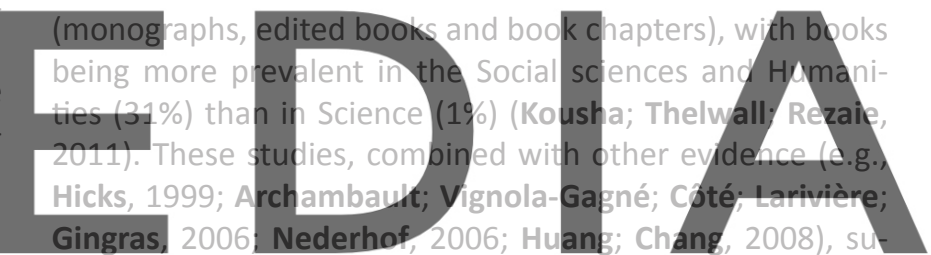

ggest that the coverage of WoS and Scopus for both articles and hooks could be insufficient for bibliometric analyses of inclusion of some books and monographs in both databases.

It is important to be clear that even in Science and Medicine citation counts are only research impact indicators and do not directly measure the quality of an article. The clearest evidence for this is that duplicate articles published in high impact journals seem to attract twice as many citations as identical versions published in lower impact journals, suggesting that citations may partly reflect the prestige of the publishing journal (Larivière; Gingras, 2010), or that the audience for an article may partly reflect the publication venue. Journal impact factors are particularly controversial and are not recommended for research evaluation purposes because of their many limitations, such as variability over time and the unfairness of comparing between different types of journals and between journals in different fields (Seglen, 1997; Sombatsompop; Markpin, 2005). Citation indicators also cannot be used for recently published papers because they need time to accrue enough citations for a reasonable assessment and in some subject areas, such as the Social Sciences, research takes longer to be cited (Glänzel; Schoepflin, 1995; Glänzel; Schlemmer; Thijs, 2003). Hence, citation indicators should not be used to compare articles in different fields (unless field normalised), published in di- 
fferent years (unless time normalised) or of different types. More extensive reviews of citation-based indicators, normalisation issues and applications are available elsewhere (Moed, 2005a; Wouters et al., 2015).

\section{Web-based scholarly databases}

The Web contains free general scholarly databases, such as Google Scholar and Microsoft Academic Search (although the latter seemed to have virtually stopped indexing new documents by 2014: Orduña-Malea; Ayllón; Martín-Martín; Delgado-López-Cózar, 2014), as well as institutional and subject repositories (e.g., ADS, AgEcon, arXiv, CiteSeerX, Dryad, PhilPapers, PubMed, RePEc, SSRN - see also http:// www.opendoar.org) some of which report citation or usage data. These inherit many of the strengths and limitations of traditional bibliometric databases, but with important differences.

\subsection{Google Scholar}

Google Scholar (GS) is a free online academic search engine that uses automated software to extract citations from online digital publications and combines it with data provided by some publishers. Many researchers use it to search for academic publications (Nicholas; Clark; Rowlands; Jamali, 2009; Herrera, 2011), as well as to promote their publications or impact by generating Google Scholar Citation (GSC) profiles (Ortega; Aguillo, 2012). For instance, a survey of 220 science and Engineering scie versity showed that GS was seco

for coutine literature searches (Hightower; Caldwell, 2010). ,000 university faculty in the United States found that Goocasionally" used (about 70\%) to find academic publications

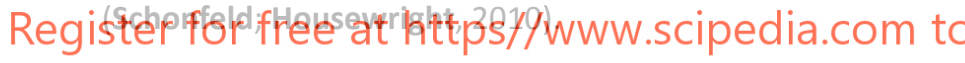
Although GS was not primarily developed to rival conventional citation indexes, many studies have compared it against them for research assessment (see Appendix A). GS covers a wider range of academic journals and millions of other scholarly-related publications in different languages and countries, making it particularly worth investigating for impact assessment in areas that are not well covered by WoS or Scopus.

Google does not allow routine automatic gathering data from GS but has apparently made an exception for the $P u$ blish or Perish software:

http://www.harzing.com/pophelp/faq.htm\#Q1010

developed to compute research impact indicators (e.g., the h-index) from GS data (Harzing; Van der Wal, 2008). The superior coverage of GS in Computer Science and Informatics in the UK Research Excellence Framework (REF, a successor to the $R A E$ ) has led to it being recognised as helpful to assist peer review when Scopus-indexed citations are inadequate (REF, 2012). A team of scientometricians has also recommended GS citations for the individual assessment of researchers in the EU (after checking for false matches), when evaluators, research committees and funders need complementary or wider impact indicators (Acumen portfolio, 2014).

\subsubsection{Google Scholar coverage vs. conventional citation indexes}

Unfortunately, it is not possible to accurately estimate the coverage of GS (Orduña-Malea; Ayllón; Martín-Martín; Delgado-López-Cózar, 2015), but it appears to cover about 88\% (100 out of 114 million) of the English-language scholarly documents accessible on the web (Khabsa; Giles, 2014) which seems to be about double the size of WoS (about 51 million records, including conference proceedings by September $\left.2014^{1}\right)$. GS also seems to have comparable coverage of high impact scientific journals. A 2006 study, for instance, found that GS covers an overwhelming majority of the journals in the Thomson-Reuters Science (86\%), Social Sciences (88\%) and Arts and Humanities (81\%) Citation Indexes (Mayr; Walter, 2007). Since then, the current and retroactive coverage of GS appears to have expanded in many Science fields (e.g., Chen, 2010; Harzing, 2014, 2013; De Winter; Zadpoor; Dodou, 2014; Orduna-Malea; Delgado-López-Cózar, 2014). Many studies have confirmed that GS has greater coverage of international and non-traditional publications (see Appendix A), suggesting that it could be useful for assessing citation impact outside that covered by conventional citation indexes (e.g., Meho; Yang, 2007; Bar-llan, 2008; Kulkarni; Aziz; Shams; Busse, 2009; Franceschet, 2010; Kousha; TheIwall; Rezaie, 2011; De Groote; Raszewski, 2012; Minasny; Hartemink; McBratney; Jang, 2013).

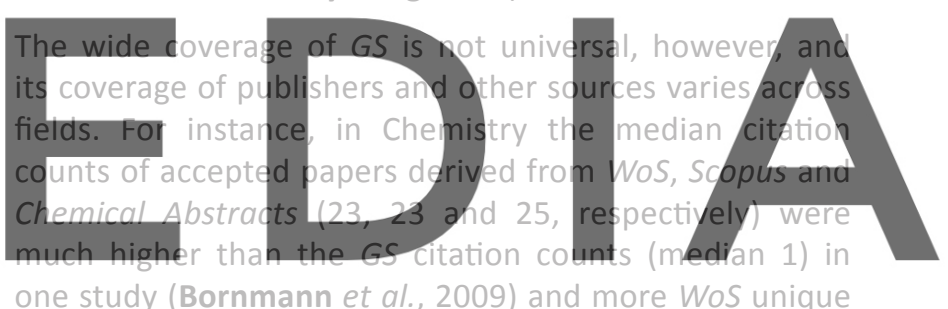

one study (Bornmann et al., 2009) and more WoS unique

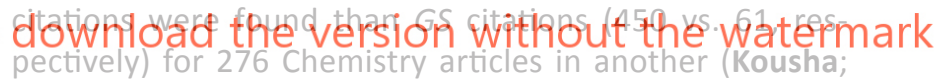
Thelwall, 2008b) These results may have been affected by subsequent agreements between Googie Scholar and publishers, however. In contrast, a comparison of the $h$ index for 5,283 computer scientists derived from GS and WoS showed that the mean h-index from GS (3.54) was higher than the mean h-index from WoS (2.19), but the reverse was true for 1,354 physicists (GS h-index mean 6.7 and WoS h-index mean 7.15) (Henzinger; Suñol; Weber, 2009). A comparison of citations to 1,000 books submitted to the 2008 UK Research Assessment Exercise (RAE) across seven book-based disciplines also found that both the numbers and medians of GS citations to books were three times higher than the comparable Scopus citations (Kousha; Thelwall; Rezaie, 2011). This suggests that, in addition to Computer Science, GS may be more useful for Arts and Humanities research than is WoS. The same may be true for Business because a study of the publications of Canadian business school faculty members found that the mean number of publications (22), citations (271), and the h-index (4.6) derived from GS were much higher than from WoS (5, 51 and 1.9, respectively) (Amara; Landry, 2012) and the GS mean citations per paper were almost double those of WoS for the research outputs of three UK busi- 
ness and management schools (Mingers; Lipitakis, 2010). Nevertheless, the coverage of GS may have expanded since some or all of these studies were completed.

The value of Google Scholar citation counts in research evaluation can be best assessed by comparing them with peer review judgments of academic articles. A study of articles submitted for the Research Excellence Framework (REF) 2014 correlated Google Scholar citations with peer judgements by 36 panels of disciplinary experts grading on a five point scale $\left(0,1^{*}, 2^{*}, 3^{*}, 4^{*}\right.$; although most were $3^{*}$ or $4^{*}$ ) (Hefce, 2015). The articles form artificially high quality samples due their selection criteria, reducing the correlation strengths. For articles published in 2008, the oldest year covered, the correlations varied from 0.600 (Clinical Medicine, $n=2070$ ) to -0.163 (Theology, $n=45$ ). The correlations tended to be strong and positive in the Life and Physical Sciences as well as in Economics. They were small and both negative and positive in the Arts and Humanities. The correlations were at least 0.2 in all Life and Natural sciences and most Social Sciences and Engineering. The main exception was the low correlation of 0.151 ( $n=300$ ) for Architecture, Built Environment and Planning, although this includes an element of the Humanities.

Google Scholar data should not be used without extra checking for evaluations
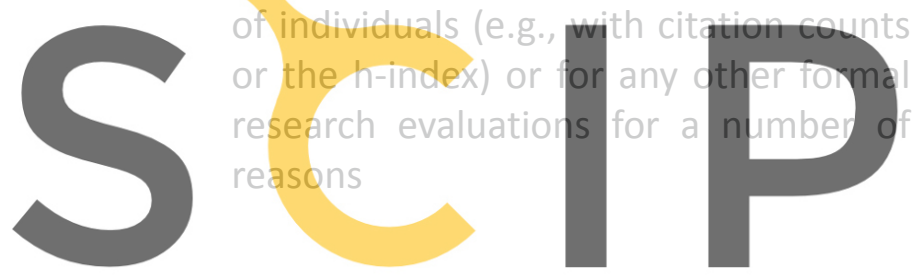

The same 2008 UK data (Hefce, 2015) makes possible, for

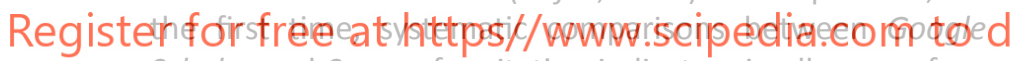
Scholar and Scopus for citation indicators in all areas of research. Google Scholar citation counts seem to be less useful than Scopus citations in Health and Natural Sciences because for all of these, Scopus citation tended to correlate a little more strongly with peer judgements than did Google Scholar citations (mean difference: 0.061). Similarly, Scopus citations tended to correlate more strongly with peer judgements than did Google Scholar citations in the five Engineering subjects (mean difference: 0.032), although Electrical and Electronic Engineering, Metallurgy and Materials is an exception. For Computer Science, in which Google Scholar has particularly good coverage, the correlation with both sources was identical $(0.484, \mathrm{n}=1035)$. In the Arts and Humanities (REF units 27-36, approximately) the reverse was true, confirming the discussion above. More specifically, Google Scholar citations tended to correlate more strongly with peer judgements than did Scopus citations in the ten Arts and Humanities subjects (mean difference: 0.024), although both History and Music, Drama, Dance and Performing Arts are exceptions. In the ten Social Sciences (REF units 17-26, approximately), the situation is more mixed, with Scopus citations having a stronger correlation with peer review in six subjects and Google Scholar citations having the stronger correlation in 4 (mean difference: 0.006). These findings about differences should not be extrapolated outside of the UK, however, except perhaps to other major English-speaking nations. Presumably correlations with peer judgements would be relatively lower for Scopus citations for these countries due to lower coverage of the national literature but it is not clear that Google Scholar coverage would also be similarly lower because this depends on the extent to which the national literature is online and indexed by Google.

\subsubsection{Problems with Google Scholar for research evaluation}

Despite the substantial, albeit occasionally patchy, Google Scholar coverage of publications and citations in comparison with conventional citation indexes, GS data should not be used without extra checking for evaluations of individuals (e.g., with citation counts or the h-index) or for any other formal research evaluations for a number of reasons. First, GS does not provide transparent information about its indexed sources and its coverage may change substantially over time without warning or notice. Most importantly, GS has no clear quality control over its indexed publications. Thus, manipulation of citation counts, automatically generated or deliberately faked documents and references as well as misidentification of authors, publication titles and years are serious concerns for those wishing to use raw statistics from GS for evaluative purposes (e.g., Norris; Oppenheim, 2007; Falagas; Pitsouni, Malietzis; Pappas, 2008; Jacsó, 2006, 2008a, 2010 and 2011; Beel; Gipp, 2010a; Beel; Gipp,

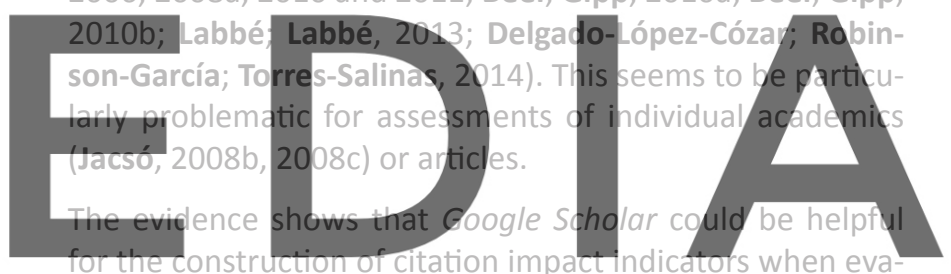

luators need a database with wider coverage than that of

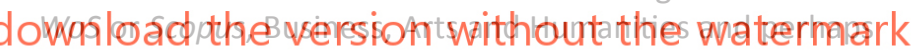
many more, although GS does not seem to provide improved coverage in some fields (this may have changed since the research reviewed above). GS also seems likely to be useful when for assessments including a substantial amount of non-English documents and perhaps also when recentlypublished or in press publications must be assessed. However, due to a lack of quality control over its indexing of web publications, GS raw data is susceptible to spamming to an extent that it should not be used unfiltered for serious research evaluation purposes. Google Scholar Citations (GSC) might be useful for the citation statistics in authors' profiles (Ortega; Aguillo, 2014), but not all authors have profiles, and there are problems with citation manipulation and errors in citation attributions.

\subsection{Patents and Google Patents}

A patent is a set of legal rights to an invention within a particular country or set of countries that is usually registered in patent offices for a period of time. Patents contain citations and, intuitively, a citation from a patent indicates that the cited document may have some commercial value or may have helped to generate commercial value. There are differences and similarities between patent and paper citations (for reviews see Meyer, 2000a; Oppenheim, 2000). For patents, both authors and examiners decide which publica- 
tions should be cited. In fact, patent examiners may add or remove applicant citations based upon judgements of relevance. Thus, patent citations could reflect the citation motivations of both examiners and applicants (Meyer, 2000a). Assuming that citations from patents can be used as evidence of the commercial impacts of research, such as influence on emerging technologies and innovations (Meyer, 2000b, 2001, 2002) or the effectiveness of research investment (Shelton; Fadel; Foland, 2015), patent databases could be used for research monitoring.

Correlations between patent citation counts from the World Intellectual Property Organization (WIPO) and peer review judgements for UK REF 2014 articles from 2008 (see the GS section above) found a maximum value of 0.229 (Clinical Medicine, $n=2070$ ), with the highest values occurring amongst engineering, life and Natural Sciences (Hefce, 2015). Nevertheless, most areas of research had too few WIPO patent citations to calculate a correlation coefficient, confirming that patents are highly subject-specific in usefulness.

\subsubsection{Impact evidence from Google Patents}

Google Patents (GP) claims to cover the full text of patents and patent applications originating from the United States Patent and Trademark Office (Uspto) from 1790 and the European Patent Office (EPO) from 1978:

https://support.google.com/faqs/answer/2539193

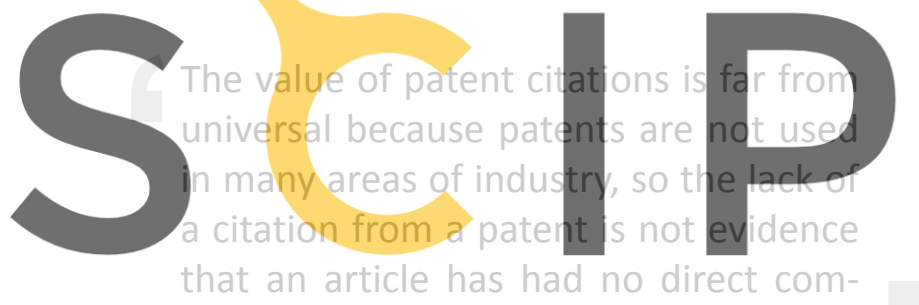

Register for

Hence, whilst not internationally comprehensive, it covers two important sources. The GP full-text search capability makes it possible to locate citations to academic publications within a large number of digitised patents. For instance, a conference paper "Viz3D: Effective exploratory visualization of large multidimensional data sets" by Artero et al. had not received any citations in WoS citation indexes (including conferences) by July 2015. At this date, however, it had been formally cited in at least 14 patents indexed by $G P$, suggesting that it may be a type of research that is more useful for inventors than for academics. A semi-automatic method has been developed to extract patent citations from Google via Bing API searches and evaluated with 322,192 Science and Engineering Scopus articles from every second year during 19962012 with sufficient accuracy and coverage for patent citation analysis. Low but statistically significant correlations between the Google Patents citations and Scopus citations are consistent with patent citations partially reflecting the commercial or technological value of scientific articles (Kousha; Thelwall, in press). The number of citations to publications from patents has been previously recommended as one way for academics to demonstrate evidence of the commercial relevance of their research (Acumen portfolio, p. 42).
Google Patents citation searches may help to identify some types of commercially relevant research. Nevertheless, the value of patent citations is far from universal because patents are not used in many areas of industry, so the lack of a citation from a patent is not evidence that an article has had no direct commercial value.

\subsection{Usage indicators from scholarly databases}

Digital readership information is now routinely collected by publishers for the electronic versions of their articles. Several early studies have shown that more cited journals tended to be more read (e.g., Stankus; Rice, 1982; Tsay, 1998) and so readership may reflect a similar type of impact to that of citations. Statistics about downloads or views of electronic articles can, in theory, also be extracted for research evaluation purposes from local library log files, digital libraries, aggregator services and scientific publishers. In addition, partial usage statistics can be obtained from some social bookmarking tools (Haustein; Siebenlist, 2011). Indicators from this data are based on the assumption that a view or download of a scholarly source indicates someone with a degree of interest or need for it (Kurtz; Bollen, 2010).

Although an early study found no connection between online views and citations for journals (Darmoni et al., 2000), later investigations have found positive associations between

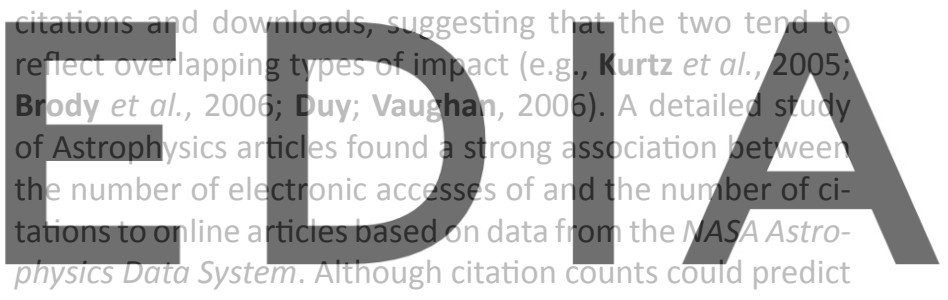

electronic accesses and vice versa, their combination is bet-

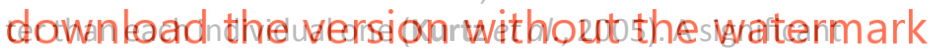
positive Spearman correlation (but very low: 0.22) has also been found between download rates and citation counts to 1,190 articles published in the journal Tetrahedron letters, during the two years after publication (Moed, 2005b). This correlation increased for downloads made after 3 months from the publication date (0.35). Similar correlations have also been found for articles deposited to arXiv.org subject categories (Brody; Harnad; Carr, 2006).

Local usage data (e.g., institutional) can also be used for download indicators and one study found them to correlate significantly ( $r=0.935,0.624$ and 0.681$)$ with the local citation data of researchers for three publishers and one Canadian university. Nevertheless, there was no association between the Journal Impact Factor and journal usage data, suggesting that local citations better reflect journal use than do global impact factors (Duy; Vaughan, 2006). Significant correlations have also been found between local online journal use provided by publishers and local journal citations for 639 journals at the California Institute of Technology (McDonald, 2007). This association was stronger than the correlations between local print use and local citations for a set of 458 journals, indicating that online journal data captures more usage than does its print counterpart. Chu and Krichel (2007) examined the relationships between ci- 
tation indicators (Social Science Citation Index and GS) and download rates for the 200 most downloaded papers from the RePEc e-print archive in economics, finding moderate statistically significant correlations between download rates for papers with citations from Social Science Citation Index citations (0.54) and Google Scholar (0.61). Another study also found significant positive correlations between different total impact factor and journal usage factor indicators in Computer Science, Economics and Finance, Oncology and Arts and Humanities (except for Psychology), although there were some disciplinary differences in the relationships between the citation and download indicators (Gorraiz; Gumpenberger; Schlögl, 2013).

It is possible to some extent to guess at the audience of an article from the IP addresses of its downloaders. For example, if the IP addresses are all associated with universities then the audience is presumably academic but if a substantial fraction comes from commercial sector organisations then this suggests a wider audience. Although it is technically possible to make such breakdowns and the wider impact evidence that they might generate would be useful for research evaluation, it is difficult to make them robust in practice. Hence, with a few exceptions (e.g., Duin; King; Van den Besselaar, 2012), this approach has not been used for evaluations.

A range of usage-oriented metrics have been proposed

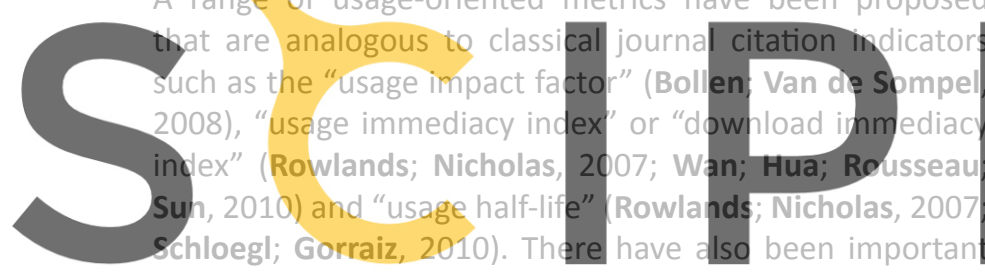

initiatives to develop platforms to collect and process usage

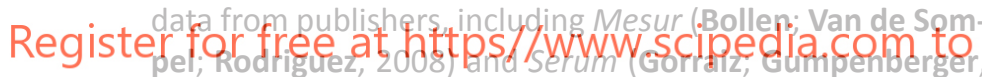

2010), in addition to the Counter initiative to standardise counting across publishers:

http://www.projectcounter.org

Nevertheless, usage statistics are not generally available for research assessment yet and they seem to be relatively easy to spam to some extent. Perhaps most tellingly, download statistics correlate substantially more weakly with peer review judgements about the quality of academic articles than do citation counts (Hefce, 2015).

\section{Citations and links from the general Web}

It is possible to extract information from the Web in order to identify citations to publications, hence using the web as a huge and uncontrolled de-facto citation database. This data collection can be automated, such as through the Bing Applications Programming Interface (API), making the web a practical, albeit somewhat tricky, source of this type of citation data. The free software Webometric Analyst: (http://lexiurl.wlv.ac.uk) can run automatic searches through the Bing API for this purpose. Commercial search engines should not be used for longitudinal comparisons, however, because changes in indexing strategies can affect the results (Van den Bosch; Bogers; De Kunder, 2015).

\subsection{Link analysis}

Over a decade ago webometric researchers attempted to assess online impact by counting web hyperlinks on the basis that, like citations, they were inter-document connections that may tend to confer authority on their targets (Almind; Ingwersen, 1997; Rousseau, 1997). This is also the idea behind Google's PageRank algorithm and so is intuitively credible. It led to the "Web Impact Factor" (Ingwersen, 1998), which was similar to the Journal Impact Factor but based on hyperlinks and applicable to any collection of websites. Online mentions of academics' names (Aguinis; Suárez-González; Lannelongue; Joo, 2012; Cronin; Snyder; Rosenbaum; Martinson; Callahan, 1998) have also been proposed as a method to identify the wider impacts or fame of academics. These initiatives all examined whether web extracted metrics could provide data for impact assessment that could extend traditional citation indicators (Cronin, 2001). Many other early investigations also exploited analogies between web links and citations to develop indicators for the impact of journal web sites or online articles (Harter; Ford, 2000; Smith, 1999; Vaughan; Hysen, 2002; Vaughan; Thelwall, 2003). On a larger scale, studies of sets of university web sites revealed that link counts correlated with the amount of research produced by universities, as measured by the $R A E$ or similar exercises (e.g., Thelwall, 2001; Smith; Thelwall, 2002; Thelwall; Harries, 2003). Nevertheless, the remo-

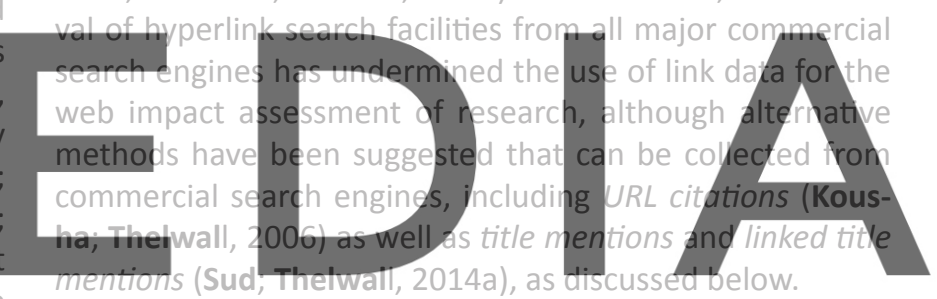

Althqugh garly studies found that counts of web hyperlinks

correlated with traditional citation metrics or other indicators of research productivity or impact, link-based metrics have not been used to assess the research of individuals. The number of links to a university website (external inlinks) is one of the indicators used for measuring the visibility of academic institutions (Aguillo; Granadino; Ortega; Prieto, 2006) in the Webometrics Ranking of World Universities, however. Hyperlink counts are now less easy to obtain and are probably not useful for assessing the impact of individual papers, academics or even research groups but may be helpful as a visibility indicator at the entire institution level, although link spam is widespread and hyperlinks can be generated automatically in large numbers for legitimate reasons, such as to connect related online databases or wikis.

\subsection{Web and URL citations}

Vaughan and Shaw $(2003,2005)$ coined the term Web citation to refer to a mention of an exact article title in a web page, proposing counts of these as a new impact indicator and showing that they tended to correlate with traditional citation-based indicators. Web citations, in this sense, can easily be identified by searches for article titles in commercial search engines. These web citation searches may return matches in the reference lists or text of any type of docu- 
ment on the Web. In contrast, an URL citation is a mention the URL of an online scholarly work (e.g., an open access article) in a web page. Both web and URL citations can be gathered manually from the online interfaces of commercial search engines or automatically by submitting queries to Bing through its free API, although more than 5,000 queries per month will need to be paid for.

URL citation counts have been used as an alternative to web citation counts with similarly promising evidence that they correlate with traditional citation counts (Kousha; Thelwall, 2006, 2007a). URL citations have the advantage that, unlike article titles, they are normally unique and hence unambiguous, but the disadvantage that many citations of online publications omit the paper's URL or use a DOI (digital object identifier) as an indirect pointer. Moreover, previous studies have shown that general Web or URL citation searches with commercial search engines gives results that need extensive manual checking to identify online citations in formal research publications because most web or URL citations seem to be created for non-scientific reasons, such as (arguably) library reading lists and online copies of journal tables of contents. For instance, out of 854 web citations to 46 library and information science journals, only 30\% were citations from other publications (Vaughan; Shaw, 2003) and only a quarter of online citations to journal articles in Biology, Physics, Chemistry, and Computing represent cita-

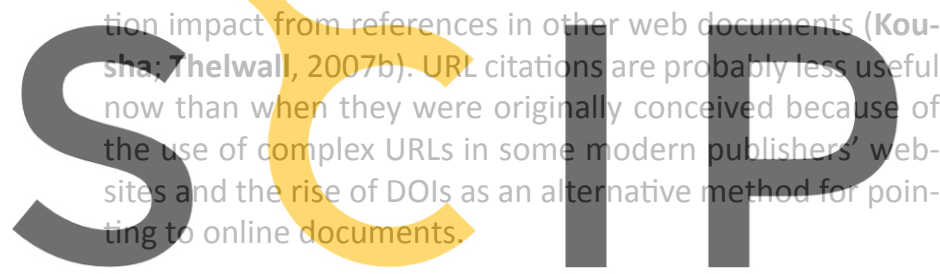

Since web or URL citations to publications can be located by Regiscmmercial search engines (Gogle manually andining auto-

they can be indicators of research impact, they could be used for indicators of the scholarly impact of research if they are filtered to remove non-scholarly sources. In contrast, unfiltered web or URL citation counts are easy to spam and many citations are created for navigation, self-publicity or current awareness and so it does not seem likely that they would genuinely reflect the wider impacts of research, without timeconsuming manual filtering out of irrelevant sources.

\section{Citations from specific parts of the general Web}

In addition to searching for citations from the general web, citations can be counted from specific parts of the web, including types of website and types of document. This information can be extracted from appropriate searches in commercial search engines and automated with the Bing API. The discussions below cover online presentations, syllabi and science blogs, although there is also some evidence that mentions in news websites and discussion forums may also be useful (Costas; Zahedi; Wouters, 2014; Thelwall, Haustein; Larivière; Sugimoto, 2013). Citations from online grey literature seem to be an additional useful source of evidence of the wider impact of research (Wilkinson; Sud; Thelwall, 2014), but there do not seem to be any systematic studies of these.

\subsection{Online presentations}

Conferences are important for sharing scientific results in some areas of Science (Drott, 1995). In Computer Science and engineering, refereed conference papers are particularly important research outputs. For example, over $40 \%$ of citations to highly cited publications in Computer Science are from proceedings papers (Bar-Ilan, 2010). The share of cited proceedings in Thomson Scientific citation indexes 1980-2005 was about 20\% in Computer Science, about 13\% in Electrical Engineering; Electronics, and 11\% in Civil Engineering. Proceedings papers tend to receive citations earlier than does the cited literature in general (Lisée; Larivière; Archambault, 2008).

Conference papers are presumably initially given with the aid of presentation files (e.g., in Microsoft .ppt and .pptx or Apple .key). Presentations in the same format may also be used for teaching and informal seminars. These presentations may then be posted online and become searchable by commercial search engines or available through slidesharing sites such as Slideshare.net. This gives them the potential to be used for a new type of online citation analysis. Although most scientific results in presentations will be formally published later in proceedings or journals, some academic presentations may never appear elsewhere. For instance, there are about 11,000 citations to PowerPoint presentation files (.ppt and.pptx) in the references of Scopus publications, a quarter of them in Computer Science
suggesting that their contentwas useful enough to be cited
by other research even though they were not formally pu-
blished. Authors' data, see:
http://www. koosha.tripod.com/citationtopowepdints.jpg
Cltations from academic publications can be systematically gathered by automatically submitting queries to commer-

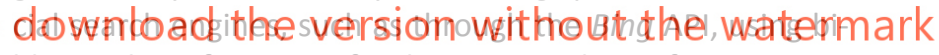
bliographic information for the query and specifying presentation files only in the results (e.g., adding filetype:ppt to each query). Based on a study of about 1,800 WoS-indexed journals in ten Science and ten Social Science fields, citations from online presentations were found to be too rare for general impact assessment, but presentation citations could be helpful to identify important articles in popular magazines like Scientific American and Harvard business review (Thelwall; Kousha, 2008). A classification of reasons for mentioning Social Science journals in 756 PowerPoint files from American university websites found that about $60 \%$ occurred in formally cited references and $15 \%$ were in course reading lists, indicating that the majority (about $75 \%)$ represented a type of intellectual impact. However, about $15 \%$ of the journals were mentioned for reasons not reflecting intellectual impact, such as CVs and publishers' lists of journals (Thelwall; Kousha, 2008). Presentations are easy to spam, however, even if they are only searched for in academic websites.

\subsection{Online course syllabi}

Course syllabi often record the most important textbooks for students to read and so are a logical source of information about whether books and articles are useful in teaching. There have been many content analyses and com- 
parative studies of the contents or structure of academic course syllabi (e.g., Pieterse et al., 2009; Mishra; Day, Littles; Vandewalker, 2011; Homa et al., 2013), but syllabi have not been used for research assessments. Nevertheless, the educational impact of publications seems to be important for teaching-based fields, and particularly in the less hierarchical knowledge structures of the Social Sciences and Humanities, where textbooks, edited books and monographs can have educational value rather than, or in addition to, research impact (e.g., Gurung; Martin, 2011; Gurung; Landrum; Daniel, 2012).

Mentions of publications (e.g., textbooks or articles) in online academic course syllabi can be automatically retrieved from the web using appropriate Bing API searches, making syllabus mentions a practical indicator for research assessment (Kousha; Thelwall, 2015). One early study searched for mentions of over 70,000 journal articles published in 2003 in online course syllabi in multiple fields, finding substantial numbers of mentions in some Social Science disciplines (e.g., Political Sciences and Information Science), but syllabus mentions were less than $13 \%$ as frequent as citations in each of the fields analysed and were less than $0.1 \%$ as frequent in mathematics. A case study of Library and Information Science articles showed that the articles that were most recommended in academic syllabi tended to be reasonably highly cited but that the converse was not

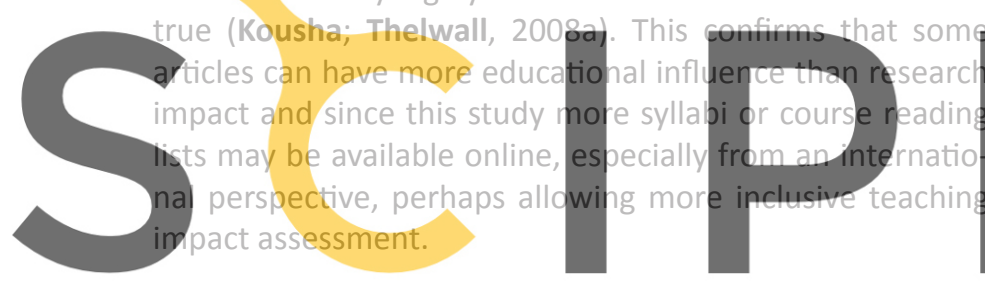

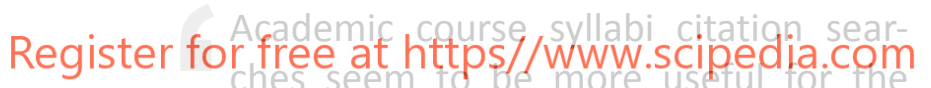
educational impacts of books and monographs

Statistics about the uptake of academic publications in academic syllabi may be useful in teaching-oriented and bookbased fields, where the main scholarly outputs of teaching staff are articles or monographs for which students are an important part of the audience, or textbooks. It is practical to harvest such data from the minority of syllabi that have been published online in the open web and indexed by search engines, but it seems that such syllabus mentions may be useful primarily to identify publications with a particularly high educational impact rather than for the systematic assessment of the educational impact of research. SyIlabus mentions have most potential for the Humanities and Social Sciences, where they are most common and where educational impact may be most important. Academic course syllabi citation searches seem to be more useful for the educational impacts of books and monographs, as discussed in Part 3 of this literature review.

\subsection{Science blogs}

There are many science blog hosting services, such as scienceblogs.com, blogs.nature.com and blogs.plos.org, where academics can discuss scientific issues. Another important genre is the medical blog, which tends to have an educated professional author that attempts to communicate the implications of research findings to the general public (Kovic; Lulic; Brumini, 2008). The contributions that academic blogs can make to informal scholarly communication have been widely recognised and analysed (e.g., Ewins, 2005; Luzón, 2007, 2009; Davies; Merchant, 2007; Kirkup, 2010; Shema; Bar-llan; Thelwall, 2012; Mewburn; Thomson, 2013; Su; Akin; Brossard; Scheufele; Xenos, 2015). In terms of authorship, about $60 \%$ of a sample of 126 ResearchBlogging.org bloggers were affiliated with academic institutions, $65 \%$ were graduate students, and $72 \%$ of ResearchBlogging.org blogs were written by one or two male authors, indicating important gender differences (Shema; Bar-Ilan; Thelwall, 2012). Academics appear to be less dominant in one German scientific blogging platform, however, and $60 \%$ declared that dissemination of their field of research to general public was their main reason for blogging (Puschmann; Mahrt, 2012). This is consistent with blogs being an alternative platform to present ideas and "to write outside the boundaries of traditional academic publication" (Davies; Merchant, 2007, p. 177; see also: Groth; Gurney,

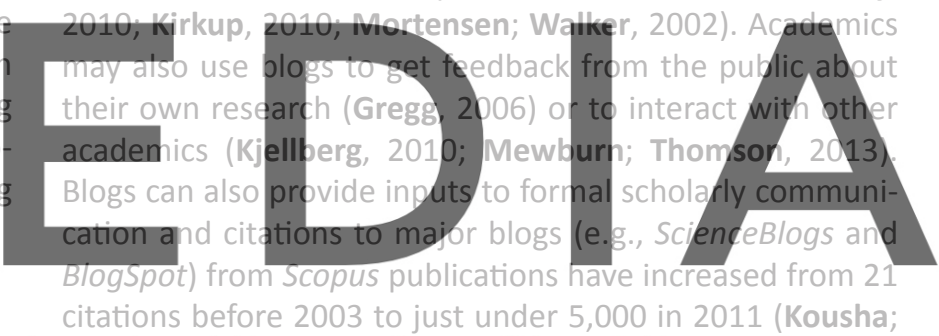
dowmilemdobhe version without the watermark

Blog posts may include links or references to other publications and these citations could perhaps be gathered to form an indicator of the impact of the cited research. Hyperlinks in academic blogs seem to be created for many informal scholarly reasons, such as to increase the visibility and collaboration of bloggers in their scientific community or to publicise their research outputs (Luzón, 2009). One study found that about $30 \%$ of academics frequently linked to articles, newspapers and other documents that they discussed or provided commentary about (Luzón, 2009). It is possible to manually search for blog citations with Google Blog Search to try to gather evidence about the social impact of the cited research, although one study found that few articles from two information science journals were cited in blogs (citation means: 0.34 and 0.44 ) in comparison to WoS (11 and 8) (Kousha, Thelwall; Rezaie, 2010).

A study using blog citation data for 13,300 Medical and Biological Sciences articles from altmetric.com (Adie; Roe, 2013) found them to correlate with WoS citation counts at a low but statistically significant level $(r=0.201 ; p<0.01)$ (TheIwall, Haustein, Larivière; Sugimoto, 2013). Another inves- 
tigation found that for $58 \%$ and $68 \%$ of journals published in 2009 and 2010, respectively, articles blogged in ResearchBlogging.org tended to subsequently receive more citations than did other articles from the same journal (Shema; BarIlan; Thelwall, 2014). These studies and the research above show that blog citations can perhaps be considered as evidence of a combination of academic interest and a potential wider social interest, even if the bloggers themselves tend to be academics. In addition, the evidence that more blogged articles are likely to receive more formal citations shows that blog citations could be used for early impact evidence. Nevertheless, blog citations are not straightforward to collect and so, as a practical step, may need to be provided by specialist altmetric software or organisations, and are easy to spam.

\section{The evidence that more blogged articles} are likely to receive more formal citations shows that blog citations could be used for early impact evidence

\subsection{Other sources of online impact}

In addition to the types of web citations discussed above, preliminary research is evaluating online clinical guidelines,

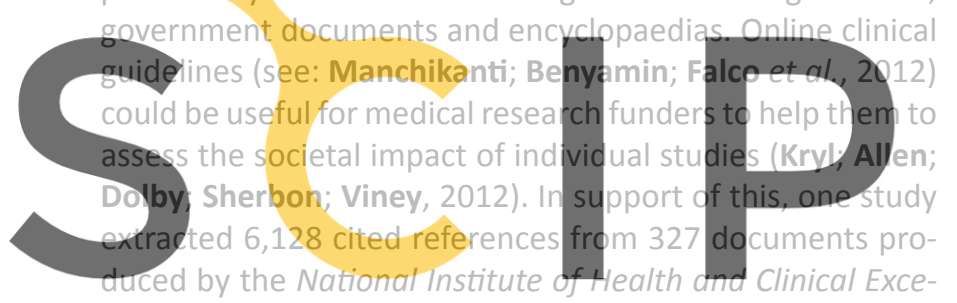

llence (NICE) in the UK, finding articles cited in guidelines

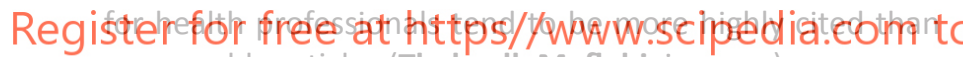
comparable articles (Thelwall; Maflahi, in press).

With millions of articles in English, many of which have references, Wikipedia is a valuable body of knowledge that may reflect wider uses of research (Bar-llan; Aharony, 2014). Moreover, references within Wikipedia articles on academic topics may be high quality selected publications (e.g., Stankus; Spiegel, 2010). Significant correlations between WoS citations to scientific journals and citations from Wikipedia, suggest that Wikipedia citations have promise for research evaluation (Nielsen, 2007). However, another study on a sample of over 24,000 articles published by the Public Library of Science showed that only $5 \%$ were cited in Wikipedia, whereas $80 \%$ had at least one Mendeley bookmark (Priem; Piwowar; Hemminger, 2012). Thus, Wikipedia citations may be too rare for routine use in research evaluation, even though they could be automatically extracted without too much difficulty from copies of Wikipedia freely provided by its owners:

http://en.wikipedia.org/wiki/Wikipedia:Database_download

\section{Conclusions}

This literature review has discussed findings about potential sources of web-based evidence about the impacts of published academic articles, excluding social web sources (covered in Part 2). The research reviewed above shows that Google Scholar is more comprehensive than WoS or Scopus for Social Science, Arts and Humanities, and Computer Science citation-based data, and, except for its potential for manipulation, seems to be better than Scopus for Arts and Humanities research, at least in the UK. It is therefore a particularly valuable source of evidence but its data cannot be collected automatically and its coverage is unknown and can be gamed, all of which are practical disadvantages.

Bibliometric indicators do not show the usage of a published work by non-authors, such as students, some academics, and non-academic users who do not usually publish but may read scholarly publications. Usage-based statistics for scientific publications may therefore help to give a better understanding of the usage patterns of documents and can be more recent than bibliometric indicators. Many studies have found correlations between usage and bibliometric indicators for articles and usage data could be extracted from different sources such as publishers, aggregator services, digital libraries and academic social web sites. Nonetheless, the usage statistics could be inflated or manipulated and some articles may be downloaded or printed but not read or may be read offline or via different websites such as authors' CVs and digital repositories (Thelwall, 2012). Hence, integrated usage statistics from different sources such as publisher's websites, repositories and academic social web

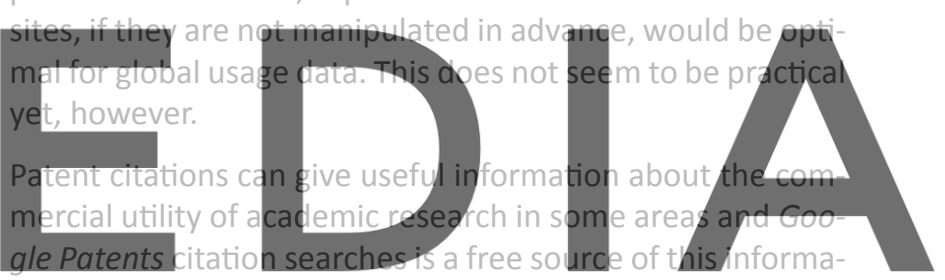

tion. Nevertheless, the value of patent citations is far from

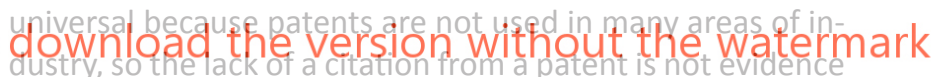 \\ that an article has had no direct commercial value.}

Citations from online presentations can be automatically collected through web searches and could perhaps be a helpful source of impact in conference-based fields, such as Computer Science and Engineering, although they seem to be too rare for this data to be worth routinely collecting for research assessment purposes. Web syllabus citations may be useful as evidence of educational impact of all types of publications and it may be possible to filter out manipulated mentions because such syllabi must be posted prominently on university websites to be credible. The main drawback of this method is that the syllabi posted online probably form a small and biased sample of the population of academic syllabi used. In contrast, citations from science blogs can be evidence of wider scholarly interest in a published work but seem to be difficult to gather systematically and so may not be a practical source of evidence. Nevertheless, they may be particularly useful to study small areas of research that generate large amounts of interest, such as controversial, popular or fraudulent science.

All of the new data sources discussed here show evidence of value for indicators of aspects of research impact but all also have limitations in practice. All are susceptible to ga- 
ming to some extent and so should not be used in formal research evaluations, but could be used in formative evaluations, such as self-evaluations. Moreover, it is not possible to gather Google Scholar citations automatically, which is a practical problem for its use in large-scale evaluations. The other indicators discussed here need some effort to collect on a large scale and so the trade-off between the amounts of time needed to gather them and the value of the information that they give needs to be considered. Their use may be made easier, however, if they are provided as part of a suite of indicators that can be gathered together. This is an attraction of academic data providers like ImpactStory, altmetric.com and Plum Analytics. When used for formative evaluations, any indicators need to be normalised for year and discipline in order to avoid being misleading. This is achieved by some altmetric data providers through a ranking percentage, such as stating that an article is in the top $10 \%$ for a given subject area and year. An alternative method is to provide the median for the field and year in addition to the raw data for a collection of articles.

For future research, ongoing studies are needed to evaluate changes in coverage of Google Scholar because of its importance as a citation index, in addition to its main literature search database role. Since its wide coverage makes it tempting for use in research evaluations, especially in nonEnglish speaking nations without good research coverage in the Web of Science or Scopus, research is also needed to assess the extent to which undesired types of content or spam are indexed in it, and whether it is possible to devise strategies to prevent authors from gaming the system. Google Patents also seems to be particularly promising as a source of commercially-related citations to academic research and seems difficult to manipulate. Studies are needed to identify whether it is useful in practice, how best to use it, and precisely which areas of research and countries can benefit from using it. It also seems to be a useful new source of wider evidence about the important issue of the connection between university research and commercial uptake. Finally, more investigations into citations from specific parts of the web (e.g., presentations, online syllabi, blogs) are needed in order to assess whether they can give useful information about the process of research and their limitations in practice, the extent of any national biases, and to develop methods to identify them in languages other than English.

\section{Note}

1. For the number of WoS records the query used in the "publication name" field was: (A* OR B* OR C* OR D* OR E* OR $\mathrm{F}^{*}$ OR G* OR H* OR I* OR J* OR K* OR L* OR M* OR N* OR O* OR P* OR Q* OR R* OR S* OR T* OR U* OR V* OR W* OR $X^{*}$ OR $Y^{*}$ OR $Z^{*}$ OR $0^{*}$ OR $1^{*}$ OR $2^{*}$ OR $3^{*}$ OR $4 *$ OR $5^{*}$ OR 6* OR 7* OR $8 *$ OR $9 *$ )

\section{Acknowledgement}

This document is an updated version of part of a review: http://www.hefce.ac.uk/media/HEFCE,2014/Content/Pubs/ Independentresearch/2015/The,Metric,Tide/2015_metrictideS1.pdf commissioned by the Higher Education Funding Council for England (Hefce) as part of the independent review of the role of metrics in research assessment that began in 2014:

\section{http://www.hefce.ac.uk/rsrch/metrics}

Thank you to members of this group for comments on earlier drafts.

\section{References}

Acumen (2014). The Acumen portfolio: Guidelines for good evaluation practice. Acumen Consortium.

http://research-acumen.eu/wp-content/uploads/D6.14Good-Evaluation-Practices.pdf

Adie, Euan; Roe, William (2013). "Altmetric: Enriching scholarly content with article-level discussion and metrics". Learned publishing, v. 26, n. 1, pp. 11-17.

http://figshare.com/articles/Enriching_scholarly_content_ with_article_level_discussion_and_metrics/105851 http://dx.doi.org/10.1087/20130103

Aguillo, Isidro F.; Granadino, Begoña; Ortega, José-Luis; Prieto, José-Antonio (2006). "Scientific research activity and communication measured with cybermetrics indicators". Journal of the American Society for Information Science and Technology, v. 57, n. 10, pp. 1296-1302.

http://dx.doi.org/10.1002/asi.20433

Aguinis, Herman; Suárez-González, Isabel; Lannelongue, Gustavo; Joo, Harry (2012). "Scholarly impact revisited". The Academy of Management Perspectives, v. 26, n. 2, pp. 105-132.

http://dx.doi.org/10.5465/amp.2011.0088

Almind, Tomas C.; Ingwersen, Peter (1997). "Informetric analyses on the World Wide Web: Methodological approaches to 'Webometrics'". Journal of documentation, $v$. 53, n. 4, pp. 404-426.

http://dx.doi.org/10.1108/EUM0000000007205

Amara, Nabil; Landry, Réjean (2012). “Counting citations in the field of business and management: Why use Google Scholar rather than the Web of Science". Scientometrics, v. 93, n. 3, pp. 553-581.

http://dx.doi.org/10.1007/s11192-012-0729-2

Archambault, Éric; Vignola-Gagné, Étienne; Côté, Grégoire; Larivière, Vincent; Gingras, Yves (2006). "Benchmarking scientific output in the social sciences and humanities: The limits of existing databases". Scientometrics, v. 68, n. 3, pp. 329-342.

http://crc.ebsi.umontreal.ca/publications/Benchmarking_ Final.pdf

Bar-Ilan, Judit (2008). "Which h-index? - A comparison of WoS, Scopus and Google Scholar". Scientometrics, v. 74, n. 2, pp. 257-271.

http://dx.doi.org/10.1007/s11192-008-0216-y

Bar-Ilan, Judit (2010). "Web of Science with the Conference proceedings citation indexes: The case of computer science". Scientometrics, v. 83, n. 3, pp. 809-824.

http://dx.doi.org/10.1007/s11192-009-0145-4

Bar-Ilan, Judit; Aharony, Noa (2014). "Twelve years of Wikipedia research". In: Proceedings of the 2014 ACM conference on Web science, pp. 243-244. New York: ACM Press. http://dl.acm.org/citation.cfm $? i d=2615569 \&$ coll $=D L \& d l=G$ UIDE\&CFID $=710889382 \&$ CFTOKEN $=29904658$ 
Bauer, Kathleen; Bakkalbasi, Nisa (2005). "An examination of citation counts in a new scholarly communication environment". D-Lib magazine, v. 11, n. 9.

http://www.dlib.org/dlib/september05/bauer/09bauer.html

Beel, Joeran; Gipp, Bela (2010a). "Academic search engine spam and Google Scholar's resilience against it". The journal of electronic publishing, v. 13, n. 3.

http://dx.doi.org/10.3998/3336451.0013.305

Beel, Joeran; Gipp, Bela (2010b). "On the robustness of Google Scholar against spam". In: Proceedings of the $21^{\text {st }}$ ACM Conf on hypertext and hypermedia, pp. 297-298.

https://www.interaction-design.org/references/conferences/ proceedings_of_the_21st_acm_conference_on_hypertext_ and_hypermedia.html

Bollen, Johan; Van De Sompel, Herbert (2008). "Usage impact factor: The effects of sample characteristics on usagebased impact metrics". Journal of the American Society for Information Science and Technology, v. 59, n. 1, pp. 136-149. http://dx.doi.org/10.1002/asi.20746

Bollen, Johan; Van De Sompel, Herbert; Rodriguez, Marko A. (2008). "Towards usage-based impact metrics: First results from the Mesur project". In: Procs of the ACM Intl conf on digital libraries, Pittsburgh, Pennsylvania, USA, pp. 231-240. http://arxiv.org/abs/0804.3791

Borgman, Christine L.; Furner, Jonathan (2002). "Scholarly communication and bibliometrics". Annual review of information science and technology, v. 36, Medford, NJ: Information Today Inc., pp. 3-72. ISBN: 9781573871310

http://polaris.gseis.ucla.edu/gleazer/296_readings/arist02.pdf

Bornmann, Lutz; Marx, Werner; Schier, Hermann; Rahm, Erhard; Thor, Andreas; Daniel, Hans-Dieter (2009). “Convergent validity of bibliometric Google Scholar data in the field of chemistry-citation counts for papers that were accepted by Angewandte Chemie International Edition or rejected but published elsewhere, using Google Scholar, Science Citation Index, Scopus, and Chemical Abstracts". Journal of informetrics, v. 3, n. 1, pp. 27-35.

http://dx.doi.org/10.1016/j.joi.2008.11.001

Brody, Tim; Harnad, Stevan; Carr, Leslie (2006). "Earlier web usage statistics as predictors of later citation impact". Journal of the American Society for Information Science and Technology, v. 57, n. 8, pp. 1060-1072.

http://dx.doi.org/10.1002/asi.20373

Butler, Linda (2008). "ICT assessment: Moving beyond journal outputs". Scientometrics, v. 74, n. 1, pp. 39-55.

http://dx.doi.org/10.1007/s11192-008-0102-7

Chen, Xiaotian (2010). “Google Scholar's dramatic coverage improvement five years after debut". Serials review, v. 36, n. 4, pp. 221-226.

http://dx.doi.org/10.1080/00987913.2010.10765321

Chu, Heting; Krichel, Thomas (2007). “Downloads vs. citations in economics: Relationships, contributing factors and beyond". In: Proceedings of ISSI $2007-11^{\text {th }}$ Intl conf of the International Society for Scientometrics and Informetrics, pp. 207-215, Madrid, Spain, June 25-27.

http://eprints.rclis.org/11085/1/DownloadsVsCitations.pdf
Costas, Rodrigo; Zahedi, Zohreh; Wouters, Paul (2014). “Do altmetrics correlate with citations? Extensive comparison of altmetric indicators with citations from a multidisciplinary perspective". arXiv preprint http://arxiv.org/abs/1401.4321

Cronin, Blaise (2001). "Bibliometrics and beyond: Some thoughts on web-based citation analysis". Journal of information science, v. 27, n. 1, pp. 1-7. http://dx.doi.org/10.1177/016555150102700101

Cronin, Blaise; Snyder, Herbert W.; Rosenbaum, Howard; Martinson, Anna; Callahan, Ewa (1998). "Invoked on the web". Journal of the American Society for Information Science, v. 49, n. 14, pp. 1319-1328

http://dx.doi.org/10.1002/(SICI)1097-4571(1998)49:14<1319::AIDASI9>3.0.CO;2-W

Da-Silva, Jaime-A.-Teixeira (2013). "The need for post-publication peer review in plant science publishing". Frontiers in plant science, 4 December.

http://dx.doi.org/10.3389/fp/s.2013.00485

Darmoni, Stefan J.; Roussel, Francis; Benichou, Jacques; Faure, Gilbert C.; Thirion, Benoit; Pinhas, Nicole (2000). "Reading factor as a credible alternative to impact factor: A preliminary study". Technology and health care, v. 8, n. 3-4, pp. 174-175.

Davies, Julia; Merchant, Guy (2007). "Looking from the inside out: Academic blogging as new literacy". In: C. Lankshear \& M. Knobel (Eds.), A new literacies sampler, pp. 167-198. New York: Peter Lang.

http://www.geocities.ws/cornerbrookresearch07/Sampler. pdf\#page $=177$

http://www.peterlang.com/index.cfm ?event=cmp.cst. ebooks. datasheet\&id $=46696$

De-Groote, Sandra L.; Raszewski, Rebecca (2012). "Coverage of Google Scholar, Scopus, and Web of Science: A case study of the h-index in nursing". Nursing outlook, v. 60, n. 6, pp. 391-400.

http://dx.doi.org/10.1016/j.outlook.2012.04.007

De-Winter, Joost C. F.; Zadpoor, Amir A.; Dodou, Dimitra (2014). "The expansion of Google Scholar versus Web of Science: A longitudinal study". Scientometrics, v. 98, n. 2, pp. 1547-1565.

http://dx.doi.org/10.1007/s11192-013-1089-2

Delgado-López-Cózar, Emilio; Robinson-García, Nicolás; Torres-Salinas, Daniel (2014). "The Google Scholar experiment: How to index false papers and manipulate bibliometric indicators". Journal of the Association for Information Science and Technology, v. 65, n. 3, pp. 446-454.

http://dx.doi.org/10.1002/asi.23056

Drott, M. Carl (1995). "Reexamining the role of conference papers in scholarly communication". Journal of the American Society for Information Science, v. 46, n. 4, pp. 299-305. http://dx.doi.org/10.1002/(SICI)1097-4571(199505)46:4<299::AIDASI6>3.0.CO;2-0

Duin, Daphne; King, David; Van-den-Besselaar, Peter (2012). "Identifying audiences of e-infrastructures-tools for measuring impact". PloS one, v. 7, n. 12, e50943. 
http://dx.doi.org/10.1371/journal.pone.0050943

Duy, Johanna; Vaughan, Liwen (2006). “Can electronic journal usage data replace citation data as a measure of journal use? An empirical examination". Journal of academic librarianship, v. 32, n. 5, pp. 512-517.

http://dx.doi.org/10.1016/j.acalib.2006.05.005

Ewins, Rory (2005). "Who are you? Weblogs and academic identity". E-learning, n. 2, pp. 368-377.

http://dx.doi.org/10.2304/elea.2005.2.4.368

Eyre-Walker, Adam; Stoletzki, Nina (2013). "The assessment of science: The relative merits of post-publication review, the impact factor, and the number of citations". PLOS biology, v. 11, n. 10: e1001675.

http://dx.doi.org/10.1371/journal.pbio.1001675

Falagas, Matthew E.; Pitsouni, Eleni I.; Malietzis, George A.; Pappas, Georgios (2008). "Comparison of PubMed, Scopus, Web of Science, and Google Scholar: Strengths and weaknesses". Faseb journal, v. 22, n. 2, pp. 338-342.

http://dx.doi.org/10.1096/fj.07-9492LSF

Franceschet, Massimo (2010). "A comparison of bibliometric indicators for computer science scholars and journals on Web of Science and Google Scholar". Scientometrics, v. 83, n. 1 , pp. 243-258.

http://dx.doi.org/10.1007/s11192-009-0021-2

Franceschet, Massimo; Costantini, Antonio (2011). "The first Italian research assessment exercise: A bibliometric perspective". Journal of informetrics, v. 5, n. 2, pp. 275291.

http://dx.doi.org/10.1016/j.joi.2010.12.002

Glänzel, Wolfgang; Schlemmer, Balázs; Thijs, Bart (2003). "Better late than never? On the chance to become highly cited only beyond the standard bibliometric time horizon". Scientometrics, v. 58, n. 3, pp. 571-586.

http://dx.doi.org/10.1023/B:SCIE.0000006881.30700.ea

Glänzel, Wolfgang; Schoepflin, Urs (1995). “A bibliometric study on ageing and reception processes of scientific literature". Journal of information science, v. 21, n. 1, pp. 37-53. http://dx.doi.org/10.1177/016555159502100104

Gorraiz, Juan; Gumpenberger, Christian (2010). “Going beyond citations: Serum - A new tool provided by a network of libraries". Liber quarterly, v. 20, n. 1, pp. 80-93.

http://liber.library.uu.nl/index.php/lq/article/view/7978

Gorraiz, Juan; Gumpenberger, Christian; Schloegl, Christian (2013). "Differences and similarities in usage versus citation behaviours observed for five subject areas". In: Procs of ISSI 2013 - $14^{\text {th }}$ Conf of the International Society of Scientometrics and Informetrics, pp. 519-535. Vienna, Austria: AIT Austrian Institute of Technology GmbH Vienna.

http://www.issi2013.org/Images/ISSI_Proceedings_Volume_I.pdf

Gregg, Melissa (2006) "Feeling ordinary: Blogging as conversational scholarship". Continuum: Journal of media and cultural studies, v. 20, n. 2, pp. 147-160.

http://dx.doi.org/10.1080/10304310600641604

Groth, Paul; Gurney, Thomas (2010). "Studying scientific discourse on the web using bibliometrics: A chemistry blog- ging case study". In: Procs of the WebSci10: Extending the frontiers of society on-line, April 26-27 ${ }^{\text {th }}$. Raleigh, NC, USA. http://journal.webscience.org/308

Gurung, Regan A. R.; Landrum, R. Eric; Daniel, David B. (2012). "Textbook use and learning: A North American perspective". Psychology learning and teaching, v. 11, n. 1, pp. 87-98. http://dx.doi.org/10.2304/plat.2012.11.1.87

Gurung, Regan A. R.; Martin, Ryan C. (2011). "Predicting textbook reading: The textbook assessment and usage scale". Teaching of psychology, v. 38, n. 1, pp. 22-28. http://dx.doi.org/10.1177/0098628310390913

Harter, Stephen P.; Ford, Charlotte E. (2000). “Web-based analysis of e-journal impact: Approaches, problems, and issues". Journal of the American Society for Information Science, v. 51, n. 13, pp. 1159-1176.

http://dx.doi.org/10.1002/1097-4571(2000)9999:9999<::AIDASI1029>3.0.CO;2-P

Harzing, Anne-Wil (2013). “A preliminary test of Google Scholar as a source for citation data: A longitudinal study of Nobel Prize winners". Scientometrics, v. 94, n. 3, pp. 1057-1075. http://dx.doi.org/10.1007/s11192-012-0777-7

Harzing, Anne-Wil (2014). "A longitudinal study of Google Scholar coverage between 2012 and 2013". Scientometrics, v. 98, n. 1 , pp. 565-575.

http://dx.doi.org/10.1007/s11192-013-0975-y

Harzing, Anne-Wil; Van der Wal, Ron (2008). “Google Scholar as a new source for citation analysis". Ethics in science and environmental politics, v. 8, n. 1, pp. 61-73.

http://www.int-res.com/articles/esep2008/8/e008pp5.pdf

Haustein, Stefanie; Siebenlist, Tobias (2011). "Applying social bookmarking data to evaluate journal usage". Journal of informetrics, v. 5, n. 3, pp. 446-457.

http://dx.doi.org/10.1016/j.joi.2011.04.002

Hefce (2015). The metric tide: Correlation analysis of REF2014 scores and metrics. Supplementary Report II to the Independent review of the role of metrics in research assessment and management. Hefce.

http://dx.doi.org/10.13140/RG.2.1.3362.4162

Henzinger, Monika; Suñol, Jacob; Weber, Ingmar (2009). "The stability of the h-index". Scientometrics, 84, pp. 465-479. http://dx.doi.org/10.1007/s11192-009-0098-7

Herrera, Gail (2011). "Google Scholar users and user behaviors: An exploratory study". College and research libraries, v. 72 , n. 4, pp. 316-331.

http://dx.doi.org/10.5860/crl-125rl

Hicks, Diana (1999). "The difficulty of achieving full coverage of international social science literature and the bibliometric consequences". Scientometrics, v. 44, n. 2, pp. 193-215.

http://dx.doi.org/10.1007/BF02457380

Hightower, Christy; Caldwell, Christy (2010). "Shifting sands: Science researchers on Google Scholar, Web of Science, and PubMed, with implications for library collections budgets". Issues in science and technology librarianship, 63. http://dx.doi.org/10.5062/F4V40S4J

http://www.istl.org/10-fall/refereed3.html 
Huang, Mu-hsuan; Chang, Yu-wei (2008). "Characteristics of research output in social sciences and humanities: from a research evaluation perspective". Journal of the American Society for Information Science and Technology, v. 59, n. 11, pp. 1819-1828.

http://dx.doi.org/10.1002/asi.20885

Ingwersen, Peter (1998). "The calculation of Web impact factors". Journal of documentation, v. 54, n. 2, pp. 236-243. http://dx.doi.org/10.1108/EUM0000000007167

Jacsó, Péter (2006). "Deflated, inflated and phantom citation counts". Online information review, v. 30, n. 3, pp. 297-309. http://dx.doi.org/10.1108/14684520610675816

Jacsó, Péter (2008a). "Google Scholar revisited”. Online information review, v. 32, n. 1, pp. 102-114.

http://dx.doi.org/10.1108/14684520810866010

Jacsó, Péter (2008b). "The pros and cons of computing the h-index using Scopus". Online information review, v. 32, n. 4, pp. 524-535.

http://dx.doi.org/10.1108/14684520810897403

Jacsó, Péter (2008c). "Testing the calculation of a realistic h-index in Google Scholar, Scopus, and Web of Science for F. W. Lancaster". Library trends, v. 56, n. 4, pp. 784-815. https://goo.gl/BshryH

Jacsó, Péter (2010). “Metadata mega mess in Google Scholar". Online information review, v. 34, n. 1, pp. 175-191. http://dx.doi.org/10.1108/14684521011024191

Jacsó, Péter (2011). “Google Scholar duped and deduped the aura of 'robometrics'". Online information review, v. 35, n. 1, pp. 154-160.

http://dx.doi.org/10.1108/14684521111113632

Khabsa, Madian; Giles, C. Lee (2014). "The number of scholarly documents on the public web". PLoS one, v. 9, n. 5: e93949.

http://dx.doi.org/10.1371/journal.pone.0093949

Kirkup, Gill (2010). "Academic blogging: Academic practice and academic identity". London review of education, v. 8, n. 1, pp. 75-84.

http://oro.open.ac.uk/20714/1/Academic_blogging_ORO.pdf

Kjellberg, Sara (2010). "I am a blogging researcher: Motivations for blogging in a scholarly context". First Monday, v. 15, n. 8.

http://firstmonday.org/article/view/2962/2580

Kling, Rob; McKim, Geoffrey (1999). "Scholarly communication and the continuum of electronic publishing". Journal of the American Society for Information Science, v. 50, n. 10, pp. 890-906.

http://dx.doi.org/10.1002/(SICI)1097-4571(1999)50:10<890::AIDASI6>3.0.CO;2-8

Kling, Rob; McKim, Geoffrey (2000). "Not just a matter of time: Field differences and the shaping of electronic media in supporting scientific communication". Journal of the American Society for Information Science and Technology, v. 51, n. 14, pp. 1306-1320.

http://dx.doi.org/10.1002/1097-4571(2000)9999:9999<::AIDASI1047>3.0.CO;2-T
Kousha, Kayvan; Thelwall, Mike (2006). "Motivations for URL citations to open access library and information science articles". Scientometrics, v. 68, n. 3, pp. 501-517.

http://dx.doi.org/10.1007/s11192-006-0126-9

Kousha, Kayvan; Thelwall, Mike (2007a). “Google Scholar citations and Google Web/URL citations: A multi-discipline exploratory analysis". Journal of the American Society for Information Science and Technology, v. 58, n. 7, pp. 10551065.

http://dx.doi.org/10.1002/asi.20584

Kousha, Kayvan; Thelwall, Mike (2007b). "How is science cited on the web? A classification of Google unique web citations". Journal of the American Society for Information Science and Technology, v. 58, n. 11, pp. 1631-1644. http://dx.doi.org/10.1002/asi.20649

Kousha, Kayvan; Thelwall, Mike (2008). “Assessing the impact of disciplinary research on teaching: An automatic analysis of online syllabuses". Journal of the American Association for Information Science and Technology, v. 59, n. 13, pp. 2060-2069.

http://dx.doi.org/10.1002/asi.20920

Kousha, Kayvan; Thelwall, Mike (2008). "Sources of Google Scholar citations outside the Science Citation Index: A comparison between four science disciplines". Scientometrics, v. 74, n. 2, pp. 273-294.

http://dx.doi.org/10.1007/s11192-008-0217-x

Kousha, Kayvan; Thelwall, Mike (2014). "Web impact metrics for research assessment". In: B. Cronin \& C.R. Sugimoto, (Eds), Beyond Bibliometrics: Harnessing Multidimensional Indicators of Scholarly Impact. MIT Press. ISBN: 978 0262525510

Kousha, Kayvan; Thelwall, Mike (2015). "An automatic method for assessing the teaching impact of books from online academic syllabi". Journal of the Association for Information Science and Technology. http://dx.doi.org/10.1002/asi.23542

Kousha, Kayvan; Thelwall, Mike (in press). "Patent citation analysis with Google". Journal of the Association for Information Science and Technology.

http://onlinelibrary.wiley.com/journal/10.1002/(ISSN)23301643

Kousha, Kayvan; Thelwall, Mike; Rezaie, Somayeh (2010). "Using the web for research evaluation: The integrated online impact indicator". Journal of informetrics, v. 4, n. 1, pp. 124-135.

http://dx.doi.org/10.1016/j.joi.2009.10.003

Kousha, Kayvan; Thelwall, Mike; Rezaie, Somayeh (2011). "Assessing the citation impact of books: The role of Google Books, Google Scholar, and Scopus". Journal of the American Society for Information Science and Technology, v. 62, n. 11, pp. 2147-2164.

http://dx.doi.org/10.1002/asi.21608

Kovic, Ivor; Lulic, Ileana; Brumini, Gordana (2008). “Examining the medical blogosphere: an online survey of medical bloggers". Journal of medical internet research, v. 10, n. 3, e28. http://dx.doi.org/10.2196/jmir.1118 
Kryl, David; Allen, Liz; Dolby, Kevin; Sherbon, Beverley; Viney, lan (2012). "Tracking the impact of research on policy and practice: investigating the feasibility of using citations in clinical guidelines for research evaluation". BMJ open, v. 2, n. 2, e000897.

http://dx.doi.org/10.1136/bmjopen-2012-000897

Kulkarni, Abhaya V.; Aziz, Brittany; Shams, Iffat; Busse, Jason W. (2009). "Comparisons of citations in Web of Science, Scopus, and Google Scholar for articles published in general medical journals". JAMA - Journal of the American Medical Association, v. 302, n. 10, pp. 1092-1096.

http://dx.doi.org/10.1001/jama.2009.1307

Kurtz, Michael J.; Bollen, Johan (2010). “Usage bibliometrics". Annual Review of Information Science and Technology, 44, pp. 1-64.

http://dx.doi.org/10.1002/aris.2010.1440440108

Kurtz, Michael J.; Eichhorn, Guenther; Accomazzi, Alberto; Grant, Carolyn; Demleitner, Markus; Murray, Stephen S.; Martimbeau, Natalie; Elwell, Barbara (2005). "The bibliometric properties of article readership information". Journal of the American Society for Information Science and Technology, v. 56, n. 2, pp. 111-128.

http://dx.doi.org/10.1002/asi.20096

Labbé, Ciryl; Labbé, Dominique (2013). “Duplicate and fake publications in the scientific literature: How many SClgen papers in computer science?". Scientometrics, v. 94, n. 1, pp. 379-396.

http://dx.doi.org/10.1007/s11192-012-0781-y

Larivière, Vincent; Gingras, Yves (2010). "Brief communication: The impact factor's Matthew effect: A natural experiment in bibliometrics". Journal of the American Society for Information Science and Technology, v. 61, n. 2, pp. 424-427. http://dx.doi.org/10.1002/asi.21232

Larsen, Peder-Olesen; Von-Ins, Markus (2010). "The rate of growth in scientific publication and the decline in coverage provided by Science Citation Index". Scientometrics, v. 84, n. 3, pp. 575-603.

http://dx.doi.org/10.1007/s11192-010-0202-z

Lasda-Bergman, Elaine M. (2012). "Finding citations to social work literature: The relative benefits of using Web of Science, Scopus, or Google Scholar". Journal of academic librarianship, v. 38, n. 6, pp. 370-379.

http://dx.doi.org/10.1016/j.acalib.2012.08.002

Lee, Carole J.; Sugimoto, Cassidy R.; Zhang, Guo; Cronin, Blaise (2013). "Bias in peer review". Journal of the American Society for Information Science and Technology, v. 64, n. 1, pp. 2-17. http://dx.doi.org/10.1002/asi.22784

Lisée, Cynthia; Larivière, Vincent; Archambault, Éric (2008). "Conference proceedings as a source of scientific information: A bibliometric analysis". Journal of the American Society for Information Science and Technology, v. 59, n. 11, pp. 1776-1784. http://dx.doi.org/10.1002/asi.20888

Luzón, María-José (2007). “Academic weblogs as tools for e-collaboration among researchers". In N. Kock (Ed.), Encyclopedia of e-collaboration, pp. 1-6. New York: Idea Group.
Luzón, María-José (2009). "Scholarly hyperwriting: The function of links in academic weblogs". Journal of the American Society for Information Science and Technology, v. 60, n. 1, pp. 75-89.

http://dx.doi.org/10.1002/asi.20937

MacRoberts, Michael H.; MacRoberts, Barbara R. (1989). "Problems of citation analysis: A critical review". Journal of the American Society for Information Science, v. 40, n. 5, pp. 342-349.

http://dx.doi.org/10.1002/(SICI)1097-4571(198909)40:5<342::AIDASI7>3.0.CO;2-U

MacRoberts, Michael H.; MacRoberts, Barbara R. (1996). "Problems of citation analysis". Scientometrics, v. 36, n. 3, pp. 435-444.

http://dx.doi.org/10.1007/BF02129604

Mahdi, Surya; D’Este, Pablo; Neely, Andy D. (2008). Citation counts: Are they good predictors of RAE scores? London: Advanced Institute of Management Research.

http://www.aimresearch.org/uploads/File/Publications/ Academic\%20Publications\%202/Citations_Counts.pdf

Manchikanti, Laxmaiah; Benyamin, Ramsin M.; Falco, Frank J. E.; Caraway, David L.; Datta, Sukdeb; Hirsch, Joshua A. (2012). "Guidelines warfare over interventional techniques: is there a lack of discourse or straw man?". Pain physician, v. 15, E1-E26.

http://www.painphysicianjournal.com/current/pdf?article= MTU2MQ\%3D\%3D\&journal=65

Mayr, Philipp; Walter, Anne-Kathrin (2007). "An exploratory study of Google Scholar". Online information review, v. 31, n. 6, pp. 814-830.

http://dx.doi.org/10.1108/14684520710841784

McDonald, John D. (2007). "Understanding journal usage: A statistical analysis of citation and use". Journal of the American Society for Information Science and Technology, v. 58, n. 1, pp. 39-50.

http://dx.doi.org/10.1002/asi.20420

Meho, Lokman I.; Rogers, Yvonne (2008). “Citation counting, citation ranking, and h-index of human-computer interaction researchers: A comparison of Scopus and Web of Science". Journal of the American Society for Information Science and Technology, v. 59, n. 11, pp. 1711-1726.

http://dx.doi.org/10.1002/asi.20874

Meho, Lokman I.; Yang, Kiduk (2007). "Impact of data sources on citation counts and rankings of LIS faculty: Web of Science versus Scopus and Google Scholar". Journal of the American Society for Information Science and Technology, v. 58, n. 13, pp. 2105-2125.

http://dx.doi.org/10.1002/asi.20677

Mewburn, Inger; Thomson, Pat (2013). "Why do academics blog? An analysis of audiences, purposes and challenges". Studies in higher education, v. 38, n. 8, pp. 1105-1119. http://dx.doi.org/10.1080/03075079.2013.835624

Meyer, Martin S. (2000a). "What is special about patent citations? Differences between scientific and patent citations". Scientometrics, v. 49, n. 1, pp. 93-123. http://dx.doi.org/10.1023/A:1005613325648 
Meyer, Martin S. (2000b). "Patent citations in a novel field of technology - What can they tell about interactions between emerging communities of science and technology?". Scientometrics, v. 48, n. 2, pp. 151-178. http://dx.doi.org/10.1023/A:1005692621105

Meyer, Martin S. (2001). "Patent citation analysis in a novel field of technology - An exploration of nano-science and nano-technology". Scientometrics, v. 51, n. 1, pp. 163-183. http://dx.doi.org/10.1023/A:1010572914033

Meyer, Martin S. (2002). "Tracing knowledge flows in innovation systems". Scientometrics, v. 54, n. 2, pp. 193-212. http://dx.doi.org/10.1023/A:1016057727209

Mikki, Susanne (2010). "Comparing Google Scholar and ISI Web of Science for earth sciences". Scientometrics, v. 82, n. 2, pp. 321-331.

http://dx.doi.org/10.1007/s11192-009-0038-6

Minasny, Budiman; Hartemink, Alfred E.; McBratney, Alex; Jang, Ho-Jun (2013). "Citations and the $h$ index of soil researchers and journals in the Web of Science, Scopus, and Google Scholar". PeerJ 1:e183.

http://dx.doi.org/10.7717/peerj.183

Mingers, John; Lipitakis, Evangelina A. E. C. G. (2010). "Counting the citations: A comparison of Web of Science and Google Scholar in the field of business and management". Scientometrics, v. 85, n. 2, pp. 613-625.

http://dx.doi.org/10.1007/s11192-010-0270-0

Mishra, Jennifer; Day, Kiana; Littles, Dan; Vandewalker, Eddie (2011). "A content analysis of introductory courses in music education at NASM-accredited colleges and universities". Bulletin of the Council for Research in Music Education, n. 190, pp. 7-19.

Moed, Henk F. (2005a). Citation analysis in research evaluation. New York, New York: Springer. ISBN: 9781402037139

Moed, Henk F. (2005b). "Statistical relationships between downloads and citations at the level of individual documents within a single journal". Journal of the American Society for Information Science and Technology, v. 56, n. 10, pp. 1088-1097.

http://dx.doi.org/10.1002/asi.20200

Mortensen, Torill; Walker, Jill (2002). "Blogging thoughts: Personal publication as an online research tool". In: A. Morrison (ed.) Researching ICTs in Context, pp. 249-479. Oslo: Intermedia.

http://possibleworlds.blogs.com/blogsperiment/files/ Researching_ICTs_in_context-Ch11-Mortensen-Walker.pdf

Nederhof, Anton J. (2006). "Bibliometric monitoring of research performance in the social sciences and the humanities: A review". Scientometrics, v. 66, n. 1, pp. 81-100. http://dx.doi.org/10.1007/s11192-006-0007-2

Nielsen, Finn-Årup (2007). "Scientific citations in Wikipedia". First Monday, v. 12, n. 8.

http://firstmonday.org/htbin/cgiwrap/bin/ojs/index.php/ $\mathrm{fm} /$ article/view/1997/1872

Norris, Michael; Oppenheim, Charles (2007). “Comparing alternatives to the Web of Science for coverage of the social sciences' literature". Journal of informetrics, v. 1, n. 2, pp. 161-169. http://dx.doi.org/10.1016/j.joi.2006.12.001

Oppenheim, Charles (2000). “Do patent citations count?" In: B. Cronin; H. B. Atkins (Eds.). The web of knowledge: A festschrift in honor of Eugene Garfield, pp. 405-432. Metford, NJ. Information Today Inc. ISBN: 9781573870993

Orduña-Malea, Enrique; Ayllón, Juan M.; Martín-Martín, Alberto; Delgado-López-Cózar, Emilio (2015). "Methods for estimating the size of Google Scholar". Scientometrics, v. 104, n. 3, pp. 931-949.

http://dx.doi.org/10.1007/s11192-015-1614-6

Orduña-Malea, Enrique; Delgado-López-Cózar, Emilio (2014). "Google Scholar metrics evolution: An analysis according to languages". Scientometrics, v. 98, n. 3, pp. 2353-2367. http://dx.doi.org/10.1007/s11192-013-1164-8

Ortega, José-Luis; Aguillo, Isidro F. (2012). "Science is all in the eye of the beholder: Keyword maps in Google Scholar citations". Journal of the American Society for Information Science and Technology, v. 63, n. 12, pp. 2370-2377.

http://dx.doi.org/10.1002/asi.22761

Ortega, José-Luis; Aguillo, Isidro F. (2014). “Microsoft academic search and Google Scholar citations: Comparative analysis of author profiles". Journal of the Association for Information Science and Technology, v. 65, n. 6, pp. 1149-1156. http://dx.doi.org/10.1002/asi.23036

Pieterse, Alex L.; Evans, Sarah A.; Risner-Butner, Amelia; Collins, Noah M.; Mason, Laura-Beth (2009). "Multicultural competence and social justice training in counseling psychology and counselor education: A review and analysis of a sample of multicultural course syllabi". Counseling psychologist, v. 37, n. 1, pp. 93-115.

http://dx.doi.org/10.1177/0011000008319986

Priem, Jason; Piwowar, Heather; Hemminger, Bradley M. (2012). Altmetrics in the wild: Using social media to explore scholarly impact.

http://arXiv.org/html/1203.4745v1

Priem, Jason; Taraborelli, Dario; Groth, Paul; Neylon, Cameron (2010). Altmetrics: A manifesto.

http://altmetrics.org/manifesto

Puschmann, Cornelius; Mahrt, Merja (2012). "Scholarly blogging: A new form of publishing or science journalism 2.0?" In: A. Tokar, M.; Beurskens, S.; Keuneke, M.; Mahrt, I.; Peters, C.; Puschmann, K.; Weller; T. van Treeck (Eds.) Science and the Internet, pp. 171-182. Düsseldorf: Düsseldorf University Press.

http://journals.lub.lu.se/index.php/sciecominfo/article/ view/7292/6102

REF (2011). Decisions on assessing research impact. http://www.ref.ac.uk/media/ref/content/pub/ decisionsonassessingresearchimpact/01_11.pdf

REF (2012). Panel criteria and working methods.

http://www.ref.ac.uk/media/ref/content/pub/ panelcriteriaandworkingmethods/01_12.doc

Rousseau, Ronald (1997). "Sitations: An exploratory study". Cybermetrics, v. 1, n. 1. 
http://cybermetrics.cindoc.csic.es/articles/v1i1p1.html

Rowlands, Ian; Nicholas, David (2007). "The missing link: Journal usage metrics". In: Aslib proceedings: New information perspectives, v. 59, n. 3, pp. 222-228.

http://dx.doi.org/10.1108/00012530710752025

Schloegl, Christian; Gorraiz, Juan (2010). "Comparison of citation and usage indicators: The case of oncology journals". Scientometrics, v. 82, n. 3, pp. 567-580.

http://dx.doi.org/10.1007/s11192-010-0172-1

Schonfeld, Roger C.; Housewright, Ross (2010). Faculty survey 2009: Key strategic insights for libraries, publishers, and societies. Ithaka S+R, New York, NY.

http://www.sr.ithaka.org/sites/default/files/reports/ Faculty_Study_2009.pdf

Seglen, Per O. (1997). "Why the impact factor of journals should not be used for evaluating research". British medical journal, v. 314, n. 7079, pp. 498-502.

http://dx.doi.org/10.1136/bmj.314.7079.497

Shelton, Robert-Duane; Fadel, Tarek R.; Foland, Patricia (2015). "Causal connections between scientometric indicators: Which ones best explain high-technology manufacturing outputs?" In: Proceedings of ISSI 2015 - 15 $5^{\text {th }}$ Int conf of the International Society for Scientometrics and Informetrics. Istanbul, Turkey: Boğaziçi University Printhouse, pp. 662-672.

Shema, Hadas; Bar-Ilan, Judit; Thelwall, Mike (2012). "Research blogs and the discussion of scholarly information". PLoS one, v. 7, n. 5.

http://dx.doi.org/10.1371/journal.pone.0035869

Shema, Hadas; Bar-Ilan, Judit; Thelwall, Mike (2014). "Do blog citations correlate with a higher number of future citations? Research blogs as a potential source for alternative metrics". Journal of the Association for Information Science and Technology, v. 65, n. 5, pp. 1018-1027.

http://dx.doi.org/10.1002/asi.23037

Smith, Alastair G. (1999). "A tale of two Web spaces: Comparing sites using Web impact factors". Journal of documentation, v. 55, n. 5, pp. 577-592.

Smith, Alastair G.; Thelwall, Mike (2002). "Web impact factors for Australasian universities". Scientometrics, v. 54, n. 3, pp. 363-380.

http://dx.doi.org/10.1023/A:1016030415822

Sombatsompop, Narongrit; Markpin, Teerasak (2005). "Making an equality of ISI impact factors for different subject fields". Journal of the American Society for Information Science and Technology, v. 56, n. 7, pp. 676-683.

http://dx.doi.org/10.1002/asi.20150

Stankus, Tony; Rice, Barbara E. (1982). "Handle with care: Use and citation data for science journal management". CoIlection management, v. 4, n. 1-2, pp. 95-110.

http://dx.doi.org/10.1300/J105v04n01_07

Stankus, Tony; Spiegel, Sarah E. (2010). "Wikipedia, scholarpedia, and references to books in the brain and behavioral sciences: A comparison of cited sources and recommended readings in matching free online encyclopedia entries". Science \& technology libraries, v. 29, n. 1-2, pp. 144-164. http://dx.doi.org/10.1080/01942620903579435

Su, Leona-Yi-Fan; Akin, Heather E.; Brossard, Dominique E.; Scheufele, Dietram A.; Xenos, Michael A. (2015). "Science news consumption patterns and their implications for public understanding of science". Journalism \& mass communication quarterly. http://dx.doi.org/10.1177/1077699015586415

Sud, Pardeep; Thelwall, Mike (2014a). "Linked title mentions: A new automated link search candidate". Scientometrics, v. 101, n. 3, pp. 1831-1849.

http://dx.doi.org/10.1007/s11192-014-1374-8

Sud, Pardeep; Thelwall, Mike (2014b). "Evaluating altmetrics". Scientometrics, v. 98, n. 2, pp. 1131-1143. http://dx.doi.org/10.1007/s11192-013-1117-2

Taylor, Jim; Walker, Ian (2009). "Peer assessment of research: How many publications per staff?". Lancaster University Management School, Working Paper 2009/035. http://eprints.lancs.ac.uk/31757/1/006236.pdf

Thelwall, Mike (2001). "Extracting macroscopic information from web links". Journal of the American Society for Information Science and Technology, v. 52, n. 13, pp. 1157-1168. http://dx.doi.org/10.1002/asi.1182

Thelwall, Mike (2012). "Journal impact evaluation: A webometric perspective". Scientometrics, v. 92, n. 2, pp. 429-441. http://dx.doi.org/10.1007/s11192-012-0669-x

Thelwall, Mike; Fairclough, Ruth (2015). "The influence of time and discipline on the magnitude of correlations between citation counts and quality scores". Journal of informetrics, v. 9, n. 3, pp. 529-541.

http://dx.doi.org/10.1016/j.joi.2015.05.006

Thelwall, Mike; Harries, Gareth (2003). "The connection between the research of a university and counts of links to its web pages: An investigation based upon a classification of the relationships of pages to the research of the host university". Journal of the American Society for Information Science and Technology, v. 54, n. 7, pp. 594-602.

http://dx.doi.org/10.1002/asi.10161

Thelwall, Mike; Haustein, Stefanie; Larivière, Vincent; Sugimoto, Cassidy R. (2013). "Do altmetrics work? Twitter and ten other candidates". PLoS one, v. 8, n. 5, e64841. http://dx.doi.org/10.1371/journal.pone.0064841

Thelwall, Mike; Kousha, Kayvan (2008). “Online presentations as a source of scientific impact? An analysis of PowerPoint files citing academic journals". Journal of the American Society for Information Science \& Technology, v. 59, n. 5, pp. 805-815.

http://dx.doi.org/10.1002/asi.20803

Thelwall, Mike; Maflahi, Nabeil (in press). "Guideline references and academic citations as evidence of the clinical value of health research". Journal of the Association for Information Science and Technology. http://www.scit.wlv.ac.uk/ cm1993/papers/GuidelineMetricsPreprint. $p d f$

Tsay, Ming-Yueh (1998). "The relationship between journal use in a medical library and citation use". Bulletin of the Me- 
dical Library Association, v. 86, n. 1, pp. 31-39.

http://www.ncbi.n/m.nih.gov/pmc/articles/PMC226323

Van den Bosch, Antal; Bogers, Toine; De Kunder, Maurice (2015). "A longitudinal analysis of search engine index size". In: Proceedings of ISSI 2015 - $15^{\text {th }}$ Int l conf of the International Society for Scientometrics and Informetrics. Istanbul, Turkey: Boğaziçi University Printhouse, pp. 71-82.

Vaughan, Liwen; Hysen, Kathy (2002). "Relationship between links to journal Web sites and impact factors". Aslib proceedings: New information perspectives, v. 54, n. 6, pp. 356-361. http://dx.doi.org/10.1108/00012530210452555

Vaughan, Liwen; Shaw, Debora (2003). "Bibliographic and web citations: What is the difference?". Journal of the American Society for Information Science and Technology, v. 54, n. 14, pp. 1313-1322.

http://dx.doi.org/10.1002/asi.10338

Vaughan, Liwen; Shaw, Debora (2005). "Web citation data for impact assessment: A comparison of four science disciplines". Journal of the American Society for Information Science and Technology, v. 56, n. 10, pp. 1075-1087.

http://dx.doi.org/10.1002/asi.20199

Vaughan, Liwen; Shaw, Debora (2008). "A new look at evidence of scholarly citation in citation indexes and from web sources". Scientometrics, v. 74, n. 2, pp. 317-330.

http://dx.doi.org/10.1007/s11192-008-0220-2

Vaughan, Liwen; Thelwall, Mike (2003). "Scholarly use of the Web: What are the key inducers of links to journal Web sites?". Journal of the American Society for Information Science and Technology, v. 54, n. 1, pp. 29-38.

http://dx.doi.org/10.1002/asi.10184

Wan, Jin-kun; Hua, Ping-huan; Rousseau, Ronald; Sun, Xiukun (2010). "The journal download immediacy index (DII): Experiences using a Chinese full-text database". Scientometrics, v. 82, n. 3, pp. 555-566.

http://dx.doi.org/10.1007/s11192-010-0171-2

Warner, Julian (2000). "Critical review of the application of citation studies to the Research Assessment Exercises". Journal of information science, v. 26, n. 6, pp. 453-460 http://dx.doi.org/10.1177/016555150002600607

Weller, Ann C. (2001). Editorial peer review: Its strengths and weaknesses. Medford, N. J.: Information Today. ISBN: 1573871001

Whitley, Richard (2000). The intellectual and social organization of the sciences ( $2^{\text {ed. }}$ ), Oxford: Oxford University Press. ISBN: 0199240450

Wilkinson, David; Sud, Pardeep; Thelwall, Mike (2014). "Substance without citation: Evaluating the online impact of grey literature". Scientometrics, v. 98, n. 2, pp. 797-806. http://dx.doi.org/10.1007/s11192-013-1068-7

Wouters, Paul et al. (2015). The metric tide: Literature review (Supplementary report I to the independent review of the role of metrics in research assessment and management). Hefce.

http://dx.doi.org/10.13140/RG.2.1.5066.3520

\section{Appendix A: Comparisons between GS and conventional citation indexes}

\begin{tabular}{|c|c|c|c|}
\hline Article & Dataset / discipline & Main results & Conclusions for research evaluation \\
\hline $\begin{array}{l}\text { Bauer \& Bakkalbasi } \\
(2005)\end{array}$ & $\begin{array}{l}\text { Articles from the Journal of } \\
\text { the American Society for Infor- } \\
\text { mation Science and Technolo- } \\
\text { gy (Jasist) published in } 1985 \\
\text { (41 papers) and } 2000 \text { (105 } \\
\text { papers). }\end{array}$ & $\begin{array}{l}\text { GS retrieved } 4.5 \text { and } 3.9 \text { times more citations } \\
\text { than did WoS and Scopus, respectively, for } \\
\text { papers published in } 2000 \text {. However, WoS cita- } \\
\text { tions were } 8.7 \text { times higher than GS for older } \\
\text { papers published in } 1985 \text {. }\end{array}$ & $\begin{array}{l}\text { "A search of Google Scholar will likely reveal } \\
\text { both traditional journal articles, some of } \\
\text { which will also be covered in Web of Science } \\
\text { and Scopus, and additional unique mate- } \\
\text { rial, but the scholarly value of some of the } \\
\text { unique material remains an open question." } \\
\text { (No page, online) }\end{array}$ \\
\hline Meho \& Yang (2007) & $\begin{array}{l}\text { Over } 1,457 \text { publications by } \\
25 \text { library and information } \\
\text { researchers }\end{array}$ & $\begin{array}{l}\text { GS located } 53 \% \text { more citations than the union } \\
\text { of WoS and Scopus and increased the total } \\
\text { number of citations by } 93 \% \text {. There were sig- } \\
\text { nificant correlations between GS and both } \\
\text { WoS }(0.874) \text { and Scopus }(0.970) \text {. }\end{array}$ & $\begin{array}{l}\text { "GS stands out in its coverage of conference } \\
\text { proceedings as well as international, non- } \\
\text { English language journals." (Page: 2105). }\end{array}$ \\
\hline $\begin{array}{l}\text { Kousha \& Thelwall } \\
(2007 a)\end{array}$ & $\begin{array}{l}\text { A sample of 1,650 journal } \\
\text { articles published in } 2001 \text { in } \\
\text { Science and the Social sci- } \\
\text { ences (Biology, Chemistry, } \\
\text { Physics, Computing, Sociol- } \\
\text { ogy, Economics, Psychology, } \\
\text { and Education) }\end{array}$ & $\begin{array}{l}\text { GS citations were more numerous than WoS } \\
\text { citations in Economics ( } 769 \%) \text {, Education } \\
\text { (507\%) Computer science (201\%), Sociology } \\
\text { ( } 219 \%) \text {, Psychology ( } 200 \%) \text {, but not in Sci- } \\
\text { ence excluding Computer science (201\%). GS } \\
\text { citations highly correlated with WoS citations } \\
\text { across all fields (from } 0.825 \text { in Biology to } 0.551 \\
\text { in Education). }\end{array}$ & $\begin{array}{l}\text { "There are clear disciplinary differences } \\
\text { between conventional and Web-based ci- } \\
\text { tation patterns... and Google Scholar is a } \\
\text { more comprehensive tool for citation track- } \\
\text { ing for social science. However, the quality } \\
\text { of sources of citations (citing documents) } \\
\text { retrieved by Google Scholar is an important } \\
\text { factor to take into account" (Pages: 1063- } \\
\text { 1064) }\end{array}$ \\
\hline Mayr \& Walter (2007) & $\begin{array}{l}\text { 9,500 journals from five da- } \\
\text { tabases, Thomson Scientific } \\
\text { (SCI, SSCI, AH), Directory of } \\
\text { open access journals (DOAJ) } \\
\text { and German social sciences } \\
\text { literature (Solis) }\end{array}$ & $\begin{array}{l}\text { About } 86 \%, 88 \% \text { and } 80 \% \text { of WoS-indexed } \\
\text { journals in SCI, SSCl and } A H \text { were identified } \\
\text { in GS searches (January } 2007 \text { ), respectively. } \\
\text { About } 68 \% \text { of DOAJ journals and } 70 \% \text { of Solis } \\
\text { journals were found in GS. }\end{array}$ & $\begin{array}{l}\text { "The study shows that the majority of the } \\
\text { journals on the five lists queried can be } \\
\text { retrieved in Google Scholar... The interna- } \\
\text { tional journals from the Thomson Scientific } \\
\text { List (particularly from the area of STM) are } \\
\text { fairly well covered." (Page: } 828 \text { ). However, } \\
\text { its coverage of the DOAJ list and German } \\
\text { literature was lower than that of Thomson } \\
\text { Scientific databases. }\end{array}$ \\
\hline
\end{tabular}




\begin{tabular}{|c|c|c|c|}
\hline Meho \& Rogers (2008) & $\begin{array}{l}22 \text { top Human-computer in- } \\
\text { teraction researchers }\end{array}$ & $\begin{array}{l}\text { Average Google Scholar h indexes (20.6) were } \\
\text { higher than for Scopus ( } 12.3 \text { ) and Web of Scien- } \\
\text { ce (8.0) and there was a significant correlation } \\
\text { (Spearman 0.960) between the GS h index and } \\
\mathrm{h} \text { indexes for Scopus and WoS. }\end{array}$ & $\begin{array}{l}\text { "The main difference between the two } \\
\text { rankings is that Google Scholar helps dis- } \\
\text { tinguish between the researchers in a more } \\
\text { nuanced fashion than the union of Scopus } \\
\text { and Web of Science, as evidenced by the } \\
\text { larger variance between top-ranked and } \\
\text { bottom-ranked researchers" (Page: 1724). }\end{array}$ \\
\hline $\begin{array}{l}\text { Vaughan \& Shaw } \\
\text { (2008) }\end{array}$ & $\begin{array}{l}\text { A sample of } 1,483 \text { publica- } \\
\text { tions of Library and Informa- } \\
\text { tion Science faculty }\end{array}$ & $\begin{array}{l}\text { GS citation medians (ranging from 1-3) were } \\
\text { significantly higher than WoS citation medi- } \\
\text { ans (zero for all types of publications except } \\
\text { for books with median 1). Significant cor- } \\
\text { relations between WoS and GS citations and } \\
\text { manual ( } 0.43 \text { to } 0.75 \text { depending on the type } \\
\text { of publication) and checking of citing GS cit- } \\
\text { ing sources revealed that about } 92 \% \text { of GS } \\
\text { citations represent } \\
\text { intellectual impact (e.g., formal citations) } \\
\end{array}$ & $\begin{array}{l}\text { "In its current incarnation, Google Scholar } \\
\text { has problems. Citing and cited papers are } \\
\text { confused; and a single citation act may be } \\
\text { represented multiple times when one cit- } \\
\text { ing work appears on several web pages. In } \\
\text { spite of these problems, Google Scholar is } \\
\text { a promising tool for research evaluation. If } \\
\text { the current, beta, version of Google Scholar } \\
\text { evolves in the right direction, it could be a } \\
\text { serious challenger to WoS." (Page: } 328)\end{array}$ \\
\hline Bar-Ilan (2008) & $\begin{array}{l}47 \text { highly cited Israeli re- } \\
\text { searchers and three Nobel } \\
\text { Prize winners }\end{array}$ & $\begin{array}{l}\text { In many cases h-indexes of highly-cited Israeli } \\
\text { researchers from GS were higher than from } \\
\text { WoS and Scopus, especially for mathemati- } \\
\text { cians and computer scientists. The average } \\
\text { number of citations that the top h documents } \\
\text { received in GS (153) was much higher than in } \\
\text { WoS (21). }\end{array}$ & $\begin{array}{l}\text { "The findings show that it matters which } \\
\text { citation tool is used to compute the h-index } \\
\text { of scientists. Also there seems to be discipli- } \\
\text { nary differences in the coverage of the da- } \\
\text { tabases. The differences in citation counts } \\
\text { create a dilemma for science policy makers } \\
\text { and promotion committees." (Page: } 269 \text { ) }\end{array}$ \\
\hline $\begin{array}{l}\text { Kousha \& Thelwall } \\
\text { (2008) }\end{array}$ & $\begin{array}{l}\text { A sample of } 882 \text { articles from } \\
39 \text { ISI-indexed journals in } \\
2001 \text { from Biology, Chemis- } \\
\text { try, Physics and Computing }\end{array}$ & $\begin{array}{l}43 \% \text { of GS citations were also in WoS, although } \\
\text { there were disciplinary differences. OA articles } \\
\text { from non-WoS journals ( } 34.5 \%) \text {, conference } \\
\text { papers ( } 25.2 \%) \text {, and e-prints/preprints ( } 22.8 \%) \\
\text { were the most common sources of GS unique } \\
\text { citations and the majority of GS unique cita- } \\
\text { tions ( } 70 \%) \text { were from full-text documents. }\end{array}$ & $\begin{array}{l}\text { GS seems useful tool "for researchers using } \\
\text { the citation tracking capability of Google } \\
\text { Scholar for selecting a wider range of ci- } \\
\text { tations for their own work and non-eva- } \\
\text { luative purposes... However, the minimal } \\
\text { amount of information known about Goo- } \\
\text { gle Scholar's contents suggests caution for } \\
\text { those seeking to use its citation data for } \\
\text { research evaluation." (Page: } 290 \text { ) }\end{array}$ \\
\hline $\begin{array}{l}\text { Bornmann et al. } \\
\text { (2009) }\end{array}$ & $\begin{array}{l}1,837 \text { articles accepted for } \\
\text { publication in the journal } \\
\text { Angewandte chemie interna- } \\
\text { tional edition }\end{array}$ & $\begin{array}{l}\text { Median citations for accepted papers derived } \\
\text { from WoS SCl, Scopus and Chemical Abstracts } \\
\text { ( } 23,23 \text { and } 25 \text { respectively) were much hig- } \\
\text { her than GS citation counts (1). This was due } \\
\text { to poor coverage of the citing articles that GS } \\
\text { couldn't access through the fee-based data- } \\
\text { base providers at the time of the study. }\end{array}$ & $\begin{array}{l}\text { They concluded that in the field of Chemis- } \\
\text { try "on the one hand, the convergent validi- } \\
\text { ty of citation analyses based on data from } \\
\text { the fee-based databases and, on the other } \\
\text { hand, the lack of convergent validity of } \\
\text { the citation analysis based on the GS data." } \\
\text { (Page: } 33 \text { ). However, GS citations might } \\
\text { be beneficial for the fields of Engineering, } \\
\text { Computer Science \& Mathematics, Social } \\
\text { Sciences, Arts \& Humanities, where wider } \\
\text { publication types are needed for citation } \\
\text { analysis. }\end{array}$ \\
\hline $\begin{array}{l}\text { Kulkarni, Aziz, Shams } \\
\text { \& Busse (2009) }\end{array}$ & $\begin{array}{l}328 \text { articles published in } \\
\text { JAMA, Lancet, or the New } \\
\text { England journal of medicine } \\
\text { (October1999-March 2000) }\end{array}$ & $\begin{array}{l}\text { The GS citation median (160) was higher than } \\
\text { Scopus (149) and WoS (122). GS retrieved a me- } \\
\text { dian of } 37 \% \text { more citations for JAMA, } 32 \% \text { for } \\
\text { Lancet, and } 30 \% \text { for NEJM articles than WoS. }\end{array}$ & $\begin{array}{l}\text { "Web of Science, Scopus, and Google Scho- } \\
\text { lar produced quantitatively and qualita- } \\
\text { tively different citation counts for articles } \\
\text { published in } 3 \text { general medical journals. } \\
\text { In offering alternative scopes of coverage } \\
\text { and search algorithms, new citation data- } \\
\text { bases raise questions of how to count ci- } \\
\text { tations. For example, should a citation on } \\
\text { a non-peer-reviewed web page be viewed } \\
\text { as quantitatively equivalent to a citation in } \\
\text { a high-profile peer-reviewed medical jour- } \\
\text { nal?" (Page: 1096) }\end{array}$ \\
\hline Franceschet (2010) & $\begin{array}{l}\text { A sample of the publications } \\
\text { of a group of Italian Comput- } \\
\text { er science scholars }\end{array}$ & $\begin{array}{l}\text { GS extracted metrics were much higher than } \\
\text { those from WoS: five times higher for paper- } \\
\text { based indicators, eight times for citation- } \\
\text { based indicators and three times for } \mathrm{h} \text { type } \\
\text { indicators. There were significant correlations } \\
\text { between GS and WoS citation indicators (for } \\
\text { citations } 0.92 \text { and for the h index } 0.65 \text { ) }\end{array}$ & $\begin{array}{l}\text { "...Great care must be taken when selecting } \\
\text { the data source for the analysis. Our advice } \\
\text { here is to perform a (time-consuming) join } \\
\text { of the publications and citations contained } \\
\text { in the two databases and use the combined } \\
\text { universe to compute the } h \text { index for schol- } \\
\text { ars and journals." (Page: } 257 \text { ) }\end{array}$ \\
\hline $\begin{array}{l}\text { Henzinger, Suñol \& } \\
\text { Weber (2009) }\end{array}$ & $\begin{array}{l}5,283 \text { computer scientists } \\
\text { and } 1,354 \text { physicists in WoS } \\
\text { and GS }\end{array}$ & $\begin{array}{l}\text { The average } h \text { index derived from GS was } 3.54 \\
\text { for computer scientists and } 2.19 \text { from WoS. In } \\
\text { contrast, for physicists the average } h \text { index } \\
\text { in WoS (7.15) was slightly higher than for GS } \\
\text { (6.70), although in both fields the GS citation } \\
\text { medians were higher than those of WoS. }\end{array}$ & $\begin{array}{l}\text { They concluded that "wherever possible } \\
\text { at least two different databases should be } \\
\text { consulted and the relative ranking should } \\
\text { only be trusted if it is consistent between } \\
\text { the databases." (Page: } 473 \text { ) }\end{array}$ \\
\hline
\end{tabular}




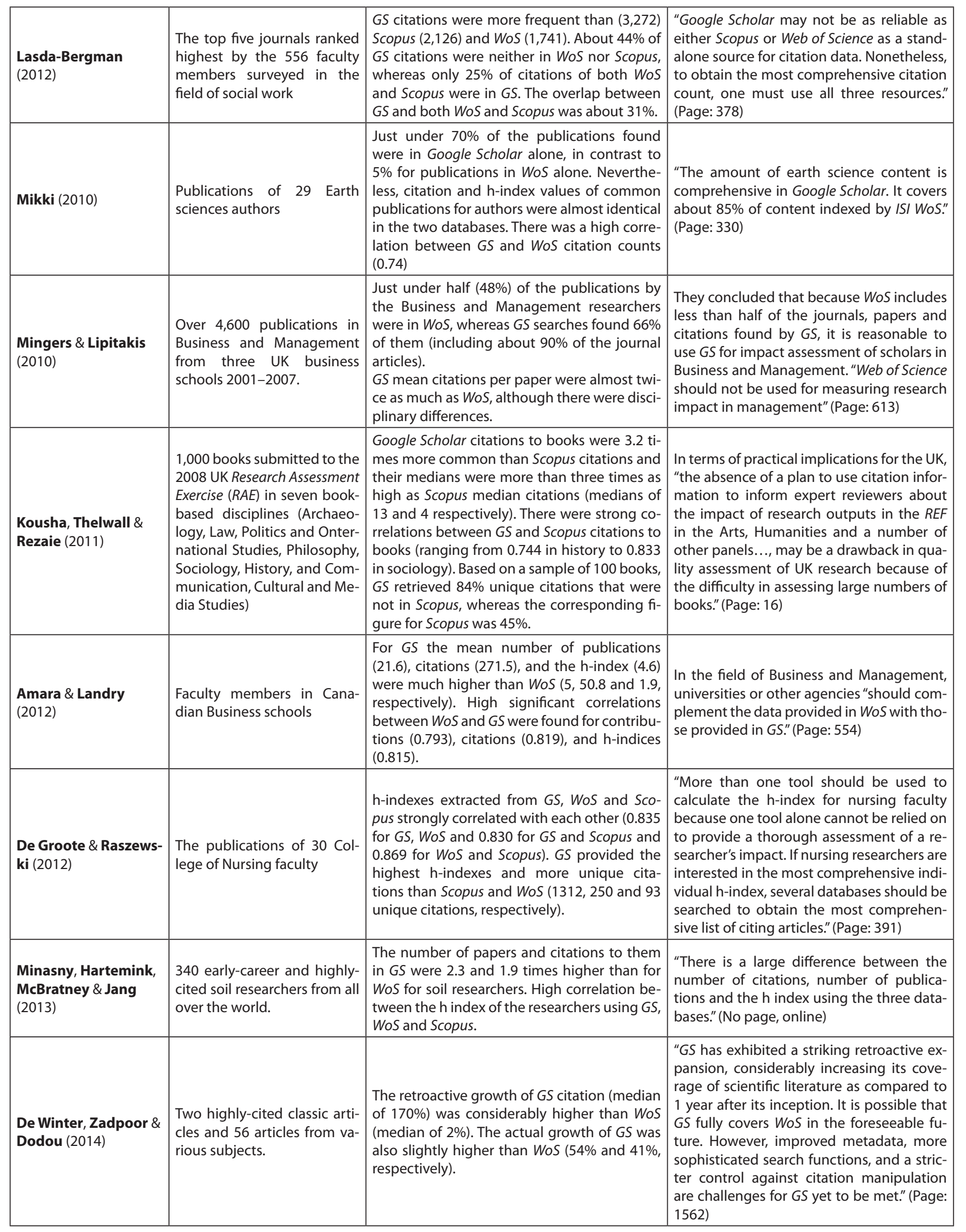

